\title{
LATE ANTIQUE OR EARLY BYZANTINE? THE SHIFTING BEGINNINGS OF BYZANTINE LITERATURE
}

\author{
PANAGIOTIS A. AGAPITOS (*) \\ Nota presentata dal m.e. Fabrizio Conca \\ (Adunanza del 12 aprile 2012)
}

SuNTO. - Lo scopo del lavoro è di esaminare le ragioni epistemologiche che stanno dietro gli sfuggenti inizi della letteratura bizantina, in un arco temporale di quattro secoli (300700 d.C.), nonché i problemi metodologici relativi allo studio di tale letteratura, emersi dalla nascita della Tarda Antichità, come un nuovo periodo storico e un nuovo campo di ricerca. D'altro canto, lo studio propone una serie di quattro criteri immanenti al testo e di sette principi operativi interni ad esso, per mezzo dei quali si può arrivare con un diverso approccio metodologico agli "inizi" della letteratura bizantina. A tale scopo le opere di Eusebio di Cesarea e di Lattanzio saranno utilizzate come base per stabilire una rottura strutturale nella produzione letteraria nelle prime due decadi del quarto secolo. Con l'intento di verificare questa ipotesi, sarà fatto un confronto con un monumento importante e oggetto di un ampio dibattito (l'Arco di Costantino a Roma) e saranno proposte alcune conclusioni sulla letteratura greca del primo periodo bizantino.

$$
* * *
$$

ABSTRACT. - The aim of the paper is twofold. On the one hand, it examines the epistemological reasons behind the shifting beginnings of Byzantine literature, a shift that covers a period of four centuries (AD 300-700), as well as the methodological problems for the study of Byzantine literature resulting from the rise of Late Antiquity as a new historical period and a new field of studies. On the other hand, the paper pro-

(*) Department of Byzantine and Modern Greek Studies, University of Cyprus, P.O.Box 20537, 1678 Nicosia, Cyprus.

E-mail: p.a.agapitos@ucy.ac.cy 
poses a series of four textually immanent criteria and seven internal operative principles by means of which a different methodological approach to the «beginning» of Byzantine literature can be reached. For this purpose Eusebios of Caesarea and Lactantius will be used as the textual basis for establishing a structural break in literary production in the first two decades of the fourth century. For the purpose of controlling this proposal a comparison with an important but highly debated monument (the Arch of Constantine in Rome) will be made and some final conclusions as to the course of Greek literature in early Byzantine times will be made.

Since the appearance of the Oxford Dictionary of Byzantium twenty years ago, there have been a number of voices pointing to the absence of a new history of Byzantine literature. ${ }^{1}$ Obviously, one major difficulty in producing such a history in the age of electronic databases and the internet is the choice of the form and the content of this kind of large book. Another difficulty is the choice of the outer and inner boundaries for such a history: Where does it begin, where does it end, where does it make a pause in order to start afresh? $?^{2}$ In the present paper I will concentrate on the beginning of Byzantine literature because it is a most complex problem in its scholarly context, as well as being a most prominent marker on account of its symbolic force in opening a grand narrative.

Over the past decades the beginning or «upper boundary» of Byzantine literature has been moving downwards; for some scholars it

1 See, for example, the various papers in P. Odorico - P.A. Agapitos (eds.), Pour une «nouvelle» histoire de la littérature byzantine: problèmes, méthodes, approches, propositions. Actes d'un colloque international philologique, Nicosie, mai 2000 [Dossiers Byzantins 1], Paris 2002, as well as the essays by A. Littlewood, Literature, in J. Harris (ed.), Palgrave Advances in Byzantine History, Basingstoke - New York 2005, pp. 133. 146 and P. Odorico, Byzantium, a literature that needs to be reconsidered, in Byzantine Manuscripts in Bucharest's Collections, Bucharest 2011, pp. 64-77.

2 Indicatively, one might compare the different approaches in the following publications: S. Impellizzeri, La letteratura bizantina da Costantino agli iconoclasti [Università degli Studi di Bari. Istituto di Storia Medievale e Moderna: Saggi 5], Bari 1965; R. Browning - M.J. Jeffreys, Byzantine Literature, Dictionary of the Middle Ages 2 (1983) 505-25; H. Hunger, Byzantinische Literatur, Lexikon des Mittelalters 2 (1983) 1182-1204; A.P. Kazhdan, A History of Byzantine Literature, 650-850. In collaboration with L.F. Sherry and C. Angelidi [National Hellenic Research Foundation. Institute for Byzantine Research: Research Series 2], Athens 1999; J.O. Rosenqvist, Die byzantinische Literatur vom 6. Jahrbundert bis zum Fall Konstantinopels 1453. Übersetzt von J.O. Rosenqvist und D.R. Reinsch, Berlin 2007 (originally published in Swedish, Stockholm 2003). 
has even reached the seventh century. ${ }^{3}$ This shift is not new. It had been already executed by Karl Krumbacher (1856-1909), the «father» of Byzantine Studies, albeit the other way round. For in the introduction to the first edition of his Geschicbte der byzantinischen Litteratur (abbreviated hereafter as GBL) he strongly argued that Byzantine literature should begin in the middle of the seventh century, that is, after the death of Emperor Herakleios and the «end» of Greek (qua classicizing) literature. ${ }^{4}$ Six years later, however, in the equivalent section of the revised and expanded introduction to the second edition of the GBL, Krumbacher decisively and in the strongest terms placed the beginning of Byzantine literature in the reign of Constantine as sole ruler (AD 324-337), now viewing the literary production in Greek from the fourth to the seventh century as frübbyzantinisch («early Byzantine»). It becomes obvious to the attentive reader of both introductions that this change was in part the result of Krumbacher's newly won familiarity with early Christian literature and with the socio-economic history of the later Roman empire. Yet, Krumbacher was forced to begin the GBL with the age of Justinian because it was there that Ivan von Müller (1830-1917), founder and first editor of the Handbuch der Klassischen Altertumswissenschaft, had placed the boundary between the ancient and the medieval world. ${ }^{6}$

The historiographical question of why the beginnings of

3 See references below in note 29.

4 K. Krumbacher, Geschichte der byzantinischen Litteratur von Justinian bis zum Ende des Oströmischen Reiches (527-1453) [Handbuch der Klassischen Altertumswissenschaft IX.1], München 1891, pp. 1-11, specifically, pp. 10-11.

5 K. Krumbacher, Gescbichte der byzantinischen Litteratur von Justinian bis zum Ende des Oströmischen Reiches (527-1453). Zweite Auflage, bearbeitet unter Mitwirkung von A. Ehrhard und H. Gelzer [Handbuch der Klassischen Altertumswissenschaft IX.1], München 1897, pp. 1-20, specifically pp. 1-2. A few years after appearance of the second edition and in a very different publication context, he took the opportunity to commit to writing his new view of the beginnings of Byzantine literature; see K. Krumbacher, Die griechische Literatur des Mittelalters, in P. Hinneberg (ed.), Die Kultur der Gegenwart: Ibre Entwicklung und ibre Ziele. Teil I, Abteilung 8, Leipzig 1905, pp. 237-285, specifically pp. 237 and 283 (two further editions of this publication appeared in 1907 and 1912 rspectively, but Krumbacher's chapter remained unaltered).

6 On the history of the Handbuch and its editor see H. Bengtson, Hundert Jahre Handbuch der Altertumswissenschaft, in W. Beck (ed.), Der Aquädukt: 1763-1988. Ein Almanach aus dem Verlag C.H. Beck im 225. Jahr seines Bestehens, München 1988, pp. 256-265. 
Byzantine literature have been shifting over the past hundred-andtwenty years is directly related to the methodological question of how these beginnings are being defined. I would call these two interrelated questions the «epistemological problem», and I shall attempt to address it briefly in the first part of my paper. In the second part, I shall offer a proposal for establishing new criteria of periodization and a suggestion for a «specific beginning» of Byzantine literature.

\section{PART I}

Let me begin with the «epistemological problem». Parallel to the formation of the model of a national state and of its national language in the first half of the nineteenth century, there also developed the model of a national literature. ${ }^{7}$ In the sense of a nation's historical continuity and its development towards the «age of progress», the beginnings of a specific nation were sought in the Middle Ages, while a national literature was created that would express the «characteristics» of this nation. ${ }^{8}$ The ideological concept of historical continuity supported the fashioning of a master narrative that presented a «history» of the creation and development of a particular national literature. 9 This fashioning was attuned to the then prevailing «biological» concepts about the birth, growth and decay of an organism, be it a

7 See J.-D. Müller, Literaturgeschichte/Literaturgeschichtsschreibung, in D. Harth - P. Gebhardt (eds.), Erkenntnis der Literatur: Theorien, Konzepte, Methoden der Literaturwissenschaft, Stuttgart 1989, pp. 195-227 and A. Compagnon, La Troisième République des Lettres, Paris 1983, pp. 19-213 for German and French literature respectively.

8 As an outstanding paradigme, one might mention G.G. Gervinus, Geschichte der poetischen National-Literatur der Deutschen. Erster Theil. Von den ersten Spuren der deutschen Dichtung bis gegen Ende des 13. Jabrbunderts, Leipzig 1835. On Gervinus and his historical-literary national project see M.S. Batts, A History of Histories of German Literature [Canadian Studies in German Language and Literature 37], New York 1987 and M. Ansel, G.G. Gervinus' Geschichte der poetischen NationalLiteratur der Deutschen: Nationbildung auf literaturgeschichtlicher Grundlage [Münchener Studien zur literarischen Kultur in Deutschland 10], Frankfurt a. M. 1990.

9 On the concept of master narrative see K.H. Jarausch - M. Sabrow, «Meistererzäblung» - Zur Karriere eines Begriffs, in K.H. Jarausch - M. Sabrow (eds.), Die historische Meistererzäblung: Deutungslinien der deutschen Nationalgeschichte nach 1945, Göttingen 2002, pp. 9-32 (with substantial bibliography). 
state or a literature. ${ }^{10}$ As a result, the concept of historical development played an important role in the formation of a biologistic master narrative for ancient Greek literature. Byzantine texts, being written in Greek, were placed in the historical period of the final decadence of Greek literature. ${ }^{11}$

An important element of the concept of historical continuity (and, concomitantly, of the notions of beginning and end) was periodization. Since the sixteenth century, a tripartition of historical time was gradually established, through which the «flow of history» had been divided into Antiquity, the Middle Ages and Modern Times. ${ }^{12} \mathrm{~A}$ most important criterion for establishing the boundary between periods was the choice of a significant historical event or of a significant historical figure as the marking point for the turn of an era. Thus, the «end» of the Roman empire in the West in the year AD $476^{13}$ was chosen as the most significant event to mark the boundary between Antiquity and the Middle Ages ${ }^{14}$ or, to put it in nineteenth-century ide-

10 See A. Demandt, Biologistische Dekadenztheorien, Saeculum 36 (1985) 4-27.

11 A telling, and stylistically most powerful example, is the «decadence» of the Greek novel from late Roman to Byzantine times as described by E. Rohde, Der griechische Roman und seine Vorläufer, Leipzig ${ }^{3} 1914$ (originally published in 1876), pp. 554-567; see the remarks of M. Alexiou, A Critical Reappraisal of Eustathios Makrembolites' «Hysmine and Hysminias», Byzantine and Modern Greek Studies 3 (1977) 23-43, specifically pp. 23-24.

12 See P.E. Hübinger, Spätantike und frühes Mittelalter: Ein Problem historischer Periodenbildung, Darmstadt 1959, pp. 5-15 for a brief but well documented overview of the concept of periods in Antiquity and the Middle Ages.

13 On this often debated end see A. Demandt, Der Fall Roms: Die Auflösung des römischen Reiches im Urteil der Nachwelt, München 1984, pp. 220-235 (more briefly in A. Demandt, Die Spätantike: Römische Geschichte von Diocletian bis Justinian, 284-565 n.Chr. [Handbuch der Altertumswissenschaft III.6], München ${ }^{2} 2007$, pp. 585593), as well as the study by A. Momigliano, La caduta senza rumore di un impero, Annali della Scuola Normale Superiore di Pisa ser. III, vol. 3.2 (1973) 397-418 (reprinted in A. Momigliano, Sesto contributo alla storia degli studi classici, Roma 1980, pp. 159180) and the essay by G. Bowersock, The Vanishing Paradigm of the Fall of Rome, in G. Bowersock, Selected Papers on Late Antiquity [Munera: Studi storici sulla Tarda Antichità 16], Bari 2000, pp. 187-197 (originally published in 1996). For a historical synthesis of the late summer of 476 see V. Marotta, Il potere imperiale dalla morte di Giuliano al crollo dell'Impero, in A. Carandini - L. Cracco Ruggini - A. Giardina (eds.), Storia di Roma. Volume 3: L'età tardoanticha. Parte I: Crisi e trasformazioni. Parte II: I luoghi e le culture, Torino 1993, vol. 3.1, pp. 551-611, specifically pp. 608-611 with further bibliography, and Demandt, Spätantike, pp. 211-217.

14 See Demandt, Spätantike, pp. 590-591. 
ological terms, the passage from the end of an overarching Roman citizen state to the beginning of the genesis of the modern European national states. ${ }^{15}$

Strongly related to the criterion of the significant event or figure for establishing historical boundaries was -especially for literature and the arts- the criterion of «ancient education». ${ }^{16}$ This criterion excercized an immense influence in shaping the image of the passage to and the nature of the Middle Ages, because the survival of ancient education (whatever that might have meant) and, consequently, the production of a classicizing literature practically became the exclusive means for measuring the cultural achievement of a particular era. In the case of Byzantine literature, more specifically, the presence of a classicizing production was seen as an indication of a strong continuity, ${ }^{17}$ while its absence was interpreted as an indication of an even stronger discontinuity. ${ }^{18}$ Hence, the «otherness» of Christian literature in the Greek language was either legitimatized through incorporation (Christian production accepted into the Greek pagan literary canon, for example,

15 It is a model that finds even today its implicit proponents, for example, A. Schiavone, The End of the Past: Ancient Rome and the Modern West. Translated by M. J. Schneider [Revealing Antiquity 13], Cambridge, MA 2000 (Italian original published in 1996), pp. 200-202.

16 See the sympathetic synthesis by W. Jaeger, Early Christianity and Greek Paideia, Cambridge, Mass. 1961 (originally published in 1934-1947) and the unsympathetic evaluation by H.-I. Marrou, Saint Augustin et la fin de la culture antique, Paris 1938; on Marrou and his change of opinion in 1948 about the «end of ancient education» see the broad analysis by F. Bolgiani, Decadenza di Roma o Tardo Antico? Alcune riflessioni sull'ultimo libro di Henri-Irénée Marrou, in S. Calderone (ed.), La storiografia ecclesiastica nella tarda antichità. Atti del convegno tenuto in Erice (3-8 xii 1978), Messina 1980, pp. 535-587. For more recent versions of the sympathetic evaluation see G. A. Kennedy, Greek Rhetoric under Christian Emperors, Princeton 1983, pp. 180-264 for Greek literature and J. Fontaine, Education and Learning, in P. Fouracre (ed.), The New Cambridge Medieval History. Volume I: c. 500-700, Cambridge 2005, pp. 735-759 (text) and 901-904 (bibliography) for Latin literature.

17 See P. Lemerle, Le premier bumanisme byzantin: Notes et remarques sur enseignement et culture à Byzance des origines au Xe siècle, Paris 1971; H. Hunger, Die hochsprachliche profane Literatur der Byzantiner [Handbuch der Altertumswissenschaft XII.5.1-2], München 1978; H.-G. Beck, Das byzantinische Jabrtausend, München 1978.

18 P. Speck, Die kaiserliche Universität von Konstantinopel [Byzantinisches Archiv 14], München 1974; C. Mango, Byzantium: The Empire of New Rome, London 1980; A.P. Kazhdan - A. Cutler, Continuity and Discontinuity in Byzantine History, Byzantion 52 (1982) 429-478. 
Gregory of $\mathrm{Nyssa}^{19}$ ) or ignored through ommission (Christian production rejected as alien to this canon, for example, early hagiography ${ }^{20}$ ).

A critical response to these ideological factors has lead over the past sixty or so years to a gradual redefinition of the traditional boundary between Antiquity and the Middle Ages. ${ }^{21}$ The spatiotemporal void resulting from this redefinition needed to be filled. Spätantike or Late Antiquity not only consolidated itself as a new era between Antiquity and the Middle Ages but, more importantly, as a new and independent area of research that brought together in an innovative manner the fields of history, archaeology and literature. ${ }^{22}$ Thus, writers such as Gregory of Nazianzus, Augustine, Claudian, Nonnos of Panopolis, Sokrates Scholastikos, Chorikios of Gaza,

19 See, indicatively, U. Gantz, Gregor von Nyssa: Oratio consolatoria in Pulcheriam [CHRESIS. Die Methode der Kirchenväter im Umgang mit der antiken Kultur 6], Basel 1999.

20 See the critical remarks by $M$. van Uytfanghe, Heiligenverehrung II (Hagiographie), Reallexikon für Antike und Christentum 14 (1987) 150-183, concerning genre in early hagiography.

21 It is a process initiated before the Second World War primarily by historians such as Ernst Stein (†1945) in his Geschichte des spätrömischen Reiches. Band 1: Vom römischen zum byzantinischen Staate (284-476 n. Chr.), Wien 1928 or Henri Pirenne $(† 1935)$ in his postumous Mahomet et Charlemagne, Bruxelles 1937 (on the latter see P. Brown, «Mohammed and Charlemagne» by Henri Pirenne, in P. Brown, Society and the Holy in Late Antiquity, Berkeley - Los Angeles 1982, pp. 63-79, originally published in 1974), and by historians of religion, such as Hans Lietzmann (†1942) in his important 1927 essay Das Problem der Spätantike, in H. Lietzmann, Kleine Schriften. I: Studien zur spätantiken Religionsgeschichte. Herausgegen von K. Aland [Texte und Untersuchungen 67], Berlin 1958, pp. 4-24 and Taf. I-III or Franz Josef Dölger (†1940) and his involvement in the foundation of the Reallexikon für Antike und Christentum in 1935 by Theodor Klauser. For the developments after 1945 see indicatively the thoughts of S. Mazzarino, La fine del mondo antico: Le cause della caduta dell'impero romano, Torino 2008 (originally published in 1959; English translation, London 1966), the contributions by various authors in A. Momigliano (ed.), The Conflict between Paganism and Christianity in the Fourth Century, Oxford 1963 and the review article by L. Cracco Ruggini, All'ombra di Momigliano: Peter Brown e la mutazione del tardoantico, Rivista Storica Italiana 100 (1988) 739-767.

22 See, indicatively, F. Clover - R.S. Humphreys, Toward a Definition of Late Antiquity, in F. Clover - R.S. Humphreys (eds.), Tradition and Innovation in Late Antiquity, Madison 1989, pp. 3-19; L. Cracco Ruggini, Il Tardoantico: Per una tipologia dei punti critici, in Carandini/Cracco Ruggini/Giardina (as above n. 13), vol. 3.1, pp. xxxiii-xliv; G.W. Bowersock - P. Brown - O. Grabar (eds.), Late Antiquity: A Guide to the Postclassical World, Cambridge, MA 1999; P. Rousseau (ed.), A Companion to Late Antiquity, Oxford 2009. 
Cassiodorus, Jordanes, or writers of Greek and Latin lives of saints and miracle collections are now being viewed as authors and cultural exponents of Late Antiquity, rather than as participants in late Roman or early Byzantine society. ${ }^{23}$ This expansive tendency has gone so far that very recent studies suggest that Byzantine intellectuals of the ninth or the eleventh century had some understanding of Late Antiquity as a historically distinct era. ${ }^{24}$ This process of transformation, whose beginnings go back to the nineteenth century, ${ }^{25}$ stepped forcefully into the foreground forty years ago. Peter Brown published his brilliant little book on The World of Late Antiquity in 1971, in which he tore down the boundaries between the various disciplines and between time and space, and argued for the unity of an «expanded» Mediterranean world that extended geographically from Ireland to Mesopotamia and chronologically from the second to the seventh century. ${ }^{26}$ Though this transformation has been criticized from various perspectives ${ }^{27}$ the concept of Late Antiquity and its autonomous his-

23 See, for example, the treatments in A. Dihle, Die griechische und lateinische Literatur der Kaiserzeit von Augustus bis Justinian, München 1989 (English translation, London - New York 1994); L.J. Engels - H. Hofmann (eds.), Spätantike, mit einem Panorama der byzantinischen Literatur [Handbuch der Literaturwissenschaft 4], Wiesbaden 1997; F. Young - L. Ayres - A. Louth (eds.), The Cambridge History of Early Christian Literature, Cambridge 2004; S.A. Harvey - D.G. Hunter (eds.), The Oxford Handbook of Early Christian Studies, Oxford 2008.

24 S. Papaioannou, The Byzantine Late Antiquity, in Rousseau (as above n. 22), pp. 17-28.

25 See J. Elsner, The Birth of Late Antiquity: Riegl and Strzygowski in 1901, Art History 25 (2002) 358-379 and M. Mazza, Spätantike: genesi e transformazioni di un tema storiografico (da Burckhardt a Mickwitz e Marrou via Riegl), Mediterraneo Antico 8 (2005) 589-638.

26 P. Brown, The World of Late Antiquity: From Marcus Aurelius to Mubammad, London 1971 (reprinted New York 1989, with an updated bibliography and brief postface); see also P. Brown, The World of Late Antiquity Revisited, Symbolae Osloenses 72 (1997) 5-90 (with contributions by G.W. Bowersock, Av. Cameron, E.A. Clark, A. Dihle, G. Fowden, P. Heather, P. Rousseau, A. Rouselle, H. Torp and I. Wood) along with the additional papers by F. Paschoud and G. Åkerström-Hougen in Symbolae Osloenses 73 (1998) 74-87 (Quelques problèmes actuels relatifs à l'historiographie de l'antiquité tardive) and 88-93 (Picture Analysis A Forgotten Method in the Research into Works of Art from the World of Late Antiquity) respectively. For a critical reading of Peter Brown's work see the review article by Lelia Cracco Ruggini quoted in $\mathrm{n} .21$.

27 See, indicatively, Av. Cameron, The Perception of Crisis, in Morfologie sociali 
torical existence has fully established itself in the broadest international academic contexts. ${ }^{28}$

As a result, Byzantine history and literature have been undergoing a similar transformation because, in an increasing number of recent publications, the upper boundary of Byzantine culture has been moving downwards to the seventh century. ${ }^{29}$ In my opinion, here lies a methodological error in the marking of this new boundary. The «rise and function of Late Antiquity» (to paraphrase the title of Peter Brown's famous paper $^{30}$ ) were described from a perspective that was based on historical events, social history and artistic production of the fourth and fifth century in the West. ${ }^{31}$ The concept of Late Antiquity

e culturali in Europa fra tarda antichità e alto medioevo, 3-9 aprile 1997 [Settimane di Studio del Centro Italiano di Studi sull'Alto Medioevo 45], Spoleto 1998, pp. 9-31; A. Giardina, Esplosione del tardoantico, Studi Storici 40 (1999) 157-180; Av. Cameron, The «Long» Late Antiquity: A Late Twentieth-century Model, in T.P. Wiseman (ed), Classics in Progress: Essays on Ancient Greece and Rome, Oxford 2002, pp. 165-191; J.H.W.G. Liebeschuetz, The Birth of Late Antiquity, Antiquité tardive 12 (2004) 253-261; P. Athanassiadi, Antiquité tardive: construction et déconstruction d'un modèle bistoriographique, Antiquité tardive 14 (2006) 311-324.

28 See the studies by H.-I. Marrou, Décadence romaine ou antiquité tardive? IIIe-VIe siècle, Paris 1977 and P. Brown, The Making of Late Antiquity, Cambridge, MA 1978, as well as the «handbook canonization» in such prestigious publications as the respective volumes of the Storia di Roma (vol. III.1-2) or of the second edition of the Cambridge Ancient History (vol. XII and the new volumes XIII-XIV, covering altogether the period AD 193-600). See also the collective presentations in S. Elm (ed.), Charisma and Society: The 25th Anniversary of Peter Brown's Analysis of the Late Antique Holy Man, Journal of Early Christian Studies 6 (1998) 343-462 (with contributions by P. Brown, M. Vessey, E.A. Clark, C. Rapp and N. Janowitz); E. Lo Cascio (ed.), Gli «spazi» del tardoantico, Studi Storici 45 (2004) 5-46 (with contributions by G.W. Bowersock, L. Cracco Ruggini, A. Marcone, A. Schiavone and A. Giardina); S. Swain - M. Edwards (eds.), Approaching Late Antiquity: The Transformation from Early to Late Empire, Oxford 2004.

29 M.D. Lauxtermann, Byzantine Poetry from Pisides to Geometres. Volume One: Texts and Contexts [Wiener Byzantinistische Studien 24.1], Wien 2003; G. Cavallo (ed.), Lo spazio letterario del Medioevo. Parte 3: Le culture circostanti. Volume I: La cultura bizantina, Roma 2004; P. Stephenson (ed.), The Byzantine World, LondonNew York 2010; L. James (ed.), A Companion to Byzantium, Oxford 2010.

30 P. Brown, The Rise and Function of the Holy Man in Late Antiquity, in P. Brown, Society and the Holy in Late Antiquity, Berkeley - Los Angeles 1982, pp. 103 152 (originally published in 1971).

31 This is evidenced in the work of Jakob Burckhardt (1818-1897) and Alois Riegl (1858-1905); see the studies referred to in $\mathrm{n}$. 25, as well as two studies by S. Mazzarino, Il basso impero: Antico, tardoantico ed èra constantiniana. Volume primo 
attempted, against the various decadence theories of the eighteenth and nineteenth century to show that the late Roman era was, in fact, historically autonomous and artistically dynamic. This attempt led to a series of radical re-interpretations and re-evaluations of society, culture and literature in the Latin-speaking western Roman empire. ${ }^{32}$

However, these new interpretive perspectives can only be projected with a substantial degree of arbitrariness upon the eastern parts of the empire because there the socio-economic, cultural, religious and linguistic context was different. The so-called unity of the expanded eastern-western late antique space cannot be so easily established on all levels simultaneously and in parallel development. ${ }^{33}$ Two examples should suffice to demonstrate this difficulty in application. On the one hand, the Greek language and its «culture» were present in the East in a very different way than they were in the West, while there existed other languages that also had an important written culture (Hebrew, Syriac, Coptic) and that interacted strongly with Greek. ${ }^{34}$ On the other hand, it is not possible to project the 476 «end

[Storia e civiltà 13], Bari 1974, pp. 11-31 (Burckhardt, il «Tardo Antico» e una lezione di Mommsen su Traiano) and pp. $32-50$ (Burckhardt politologo: «L'età di Constantino»e la moderna ideazione storiografica). For different evaluations of the same era resulting from more differentiated uses of the «western» and «eastern» perspectives see Santo Mazzarino's La fine del mondo antico (1959) as opposed to Peter Brown's The Making of Late Antiquity (1978).

32 One might indicatively refer to the following publications: M. Fuhrmann (ed.), Christianisme et formes littéraires de l'antiquité tardive en occident [Entretiens sur l'Antiquité classique 23], Genève 1977; R.A. Kaster, Guardians of Language: The Grammarian and Society in Late Antiquity, [Transformation of the Classical Heritage 11], Berkeley - Los Angeles 1988; R. Herzog (ed.), Handbuch der lateinischen Literatur der Antike. Fünfter Band: Restauration und Erneuerung: Die lateinische Literatur von 284 bis 374 n.Chr. [Handbuch der Altertumswissenschaft VIII.5.5], München 1989; J. Elsner, Art and the Roman Viewer: The Transformation of Art from the Pagan World to Christianity, Cambridge 1995; H. Inglebert, Les Romains chrétiens face à l'bistoire de Rome: Histoire, christianisme et romanités en Occident dans l'Antiquité tardive, IIIe-Ve siècles [Collection des Études Augustiniennes. Série antiquité 145], Paris 1996; J. Harries, Law and Empire in Late Antiquity, Cambridge 1999; C. Wickham, Framing the Early Middle Ages: Europe and the Mediterranean 400-800, Oxford 2006.

33 See, from rather different points of view, the critical papers by M. Mazza, Di Ellenismo, Oriente e Tarda Antichità: Considerazioni a margine di un saggio (e di un convegno), Mediterraneo Antico 1 (1998) 141-170 and Av. Cameron, Thinking with Byzantium, Transactions of the Royal Historical Society 21 (2011) 39-57.

34 G. Dagron, Aux origines de la civilisation byzantine: langue de culture et langue d'État, Revue historique 241 (1969) 23-56 (reprinted in G. Dagron, La romanité 
of Rome» in the West unto the East. ${ }^{35}$ And yet, historians have attempted to find for the East a similar break out of which a new «medieval» state -the Byzantine empire- was to emerge. This break has been placed in the seventh century during which tumultuous events brought with them immense changes in all of the Eastern Mediterranean world. ${ }^{36}$ Literary scholars have tacitly taken over this break and have placed therein the end of «ancient education» and culture. ${ }^{37}$ Here, then, lies one reason for the continuous shifting of the

chrétienne en Orient: Héritages et mutations, London 1984, no. I) and B. Rochette, Le Latin dans le monde grec: Recherches sur la diffusion de la langue et des lettres latines dans les provinces hellénophones de l'empire romain, [Collection Latomus 233], Brussels 1997; both studies move away from the venerable evaluations of H. Zilliacus, Zum Kampf der Weltsprachen im Oströmischen Reich, Helsingfors 1935.

35 See, for example, the balanced discussions by P. Fouracre, Introduction: The History of Europe 500-700, in Fouracre (as above n. 16), pp. 1-12 and by J. Shepard, Introduction. Part ii: Periodization and Contents of this Book, in J. Shepard, The Cambridge History of the Byzantine Empire, c. 500-1492, Cambridge 2008, pp. 21-52, specifically pp. 21-26.

36 From a historical and an archaeological perspective see A.P. Kazhdan - A. Cutler, Continuity and Discontinuity in Byzantine History, Byzantion 52 (1982) 429-478, specifically pp. 437-464; Mango (as above n. 18), pp. 60-87; G. Vikan (ed.), The 17th International Byzantine Congress: Major Papers. Dumbarton Oaks/Georgetown University (Washington, D.C., August 3-8, 1986), New Rochelle, NY 1986, pp. 1-116 (Part 1: The Christianization of the Empire) and 117-235 (Part 2: Transformations in Urban Life in Early Byzantium); J.H.W.G. Liebeschuetz, The Decline and Fall of the Roman City, Oxford 2001, pp. 284-317; J. Haldon, Byzantium in the Seventh Century: The Transformation of a Culture, Cambridge 1990, pp. 436-458. On the perception of the past and a notional break around AD 600 see Av. Cameron, Models of the Past in the Late Sixth Century: The Life of the Patriarch Eutychius, in G. Clarke (ed.), Reading the Past in Late Antiquity, Canberra 1990, pp. 205-223 and Av. Cameron, Byzantium and the Past in the Seventh Century: The Search for Redefinition, in J. Fontaine - J.H. Hillgarth (eds.), The Seventh Century: Change and Continuity. Proceedings of a Joint French and British Colloquium at the Warburg Institute, 8-9 July 1988 [Studies of the Warburg Institute 42], London 1992, pp. 250-276 (the two articles reprinted in Av. Cameron, Changing Cultures in Early Byzantium. Collected Studies, Aldershot 1996, nos. II and V). For very recent restatements concerning the seventh century as a break see J. Howard Johnston, Witnesses to a World Crisis: Historians and Histories of the Seventh Century, Oxford 2010, pp. 517-530 and Av. Cameron, Thinking with Byzantium (as above n. 33), pp. 55-56.

37 See Krumbacher, GBL ${ }^{1}$ (as above n. 4); W.J. Aers, Panorama der byzantinischen Literatur, in Engels/Hofmann, Spätantike (as above n. 23), pp. 635-716; Kazhdan, A History of Byzantine Literature, 650-850 (as above n. 2), pp. 7-16; Av. Cameron, New Themes and Styles in Greek Literature: A Title Revisited, in S.F. Johnson (ed.), Greek Literature in Late Antiquity: Dynamism, Didacticism, Classicism, Aldershot 
boundary between Antiquity and Byzantium. It is a boundary that cannot be stabilized because no similar historical preconditions for such a stabilization can be found as those developed for the western empire. Whatever one might think about the existence or not of Late Antiquity, one thing is certain. The periodization of history as argued by historians is external to the surviving texts. In this sense, an already existing conceptual frame is superimposed on the texts or, to express it in reverse, the texts are mechanically placed within a prefixed frame without any thought about their particular textual (qua literary and cultural) character.

\section{PART II}

The brief analysis presented in the previous pages makes it necessary to establish different criteria for the periodization of Byzantine literature. Obviously, periodization as a taxonomic tool for understanding the movement of historical time is a modern invention. It serves our scholarly needs and academic expediencies, but reflects only in the rarest of instances the notions premodern cultures might have had about «periods» in history or literary production. ${ }^{38}$ As Witold Kula, the famous Polish historian of medieval economy, brilliantly argued in his essay Reflections on history (1958), history is essentially the co-existence

2006, pp. 11-28; both Kazhdan and Cameron go back to thoughts expressed by P. Brown, A Dark Age Crisis: Aspects of the Iconoclastic Controversy, in P. Brown, Society and the Holy in Late Antiquity, Berkeley - Los Angeles 1982, pp. 251-301 (originally published in 1973). Further see Lauxtermann, Byzantine Poetry from Pisides to Geometres (as above n. 29), pp. 131-138 and Lauxtermann, La poesia, in Cavallo (as above n. 29), pp. 301-343, specifically pp. 301-311; A. Kaldellis, Hellenism in Byzantium: The Transformation of Greek Identity and the Reception of the Classical Tradition, Cambridge 2007, pp. 166-181.

38 Even then, the concept of period in literature refers to a specific event that «changed» some major aspect of literature, for example the rise of Islam in the case of Arabic poetry or the «change» of poetry in fifth-century China. See B. Dodge, The «Fibrist» of al-Nadim: A Tenth-century Survey of Muslim Culture [Records of Civilization. Sources and Studies 83], New York 1970, pp. 343-378 (where al-Nadim divides poets before and after Islam), and S. Owen, Readings in Chinese Literary Thought [Harvard-Yenching Institute Monograph Series 30], Cambridge, MA 1992, pp. 183-298 (on the sixth-century treatise of Liu Hsieh on poetics, where poetry is divided into «ancient ritual» poetry and «modern non-ritual» poetry). 
of non-synchronisms without any apparent linear development. ${ }^{39}$ In other words, history and literature consist in their spatiotemporal movement of many different structures whose continuities, discontinuities and rhythms do not fully overlap at any given moment of their coexistence.

In order, then, to understand and to describe the multileveled and ever changing fluidity of literature we must formulate a series of criteria by means of which we could detect a «structural break»; such a break would allow us to read the literary production of a given era in a methodologically satisfactory manner against its appropriate historical and socio-cultural background. I would define these criteria as «textually immanent» because they have been developed from the texts themselves. Four such criteria are:

(i) The choice of at least two contemporary authors with a voluminous work so as to conduct a satisfactory comparison on the basis of substantial textual material.

(ii) A study of the structural, generic and stylistic characteristics of the various works of the authors chosen.

(iii) A study of the «authorial consciousness» of these writers concerning: (a) their opinion about the structural, generic, stylistic or other formative elements that are to be found in their works; (b) their more general opinions as authors, possibly in relation to their real or imagined predecessors; (c) the degree of convergence, divergence or innovation as to these predecessors.

(iv) A study of the primary and secondary reception of their works, that is, on the one hand, of their immediate addressees and their contemporary audience and, on the other, of later readers.

These criteria may help to establish if there is a structural break that could be characterized as the «beginning» of Byzantine literature. Within the time span from the early fourth to the middle of the seventh century - in other words, the three-and-a-half centuries of «Late Antiquity» - there are a number of periods that have been for-

39 W. Kula, Riflessioni sulla storia. Traduzione e introduzione da M. Herling, Milano 1990, pp. 63-78. It is interesting to note that Santo Mazzarino expresses similar views about the passage from Roman to late Roman and, thus, late antique society; see an interview of his on the concept of crisis (1980), reprinted in La fine del mondo antico (as above n. 21), pp. 195-207. 
mally or informally proposed as the beginning of Byzantine literature: the sole rule of Constantine (AD 324), ${ }^{40}$ the division of the empire in $395,{ }^{41}$ the Council of Chalcedon in $451,{ }^{42}$ the reign of Justinian (527$565),{ }^{43}$ the beginning or the middle of the seventh century ${ }^{44}$ the very beginning of the eighth century. ${ }^{45}$ We might ask ourselves if the above mentioned four criteria are applicable to the following, always contemporary, authors (from the seventh back to the fourth century):

(i) George Pisides, Theophylaktos Simokates, Leontios of Neapolis, John Moschos and Sophronios of Jerusalem in the first third of the seventh century.

(ii) Prokopios of Caesarea, Romanos the Melodist, Paul the Silentiary, Flavius Cresconius Corippus, Cyril of Skythopolis and John Malalas in the reign of Justinian.

(iii) Cyril of Alexandreia, Zosimos, Sokrates Scholastikos, Nonnos of Panopolis, Sidonius Apollinaris, Proklos and Marinos of Neapolis in the fifth century.

(iv) John Chrysostom, Synesios of Cyrene, Claudius Claudianus, Ammianus Marcellinus and Eunapios of Sardis in the last quarter of the fourth century.

Each one of these authors has an important work to show, often

40 Informally: Krumbacher, GBL ${ }^{2}$ (as above n. 4); Krumbacher, Die griechische Literatur des Mittelalters (as above n. 5). Formally: Impellizzeri, La letteratura bizantina (as above n. 2); Hunger, Die hochsprachliche profane Literatur der Byzantiner (as above n. 17). An interesting example of terminological variety can be found in the respective chapters on Byzantine literature in E. Jeffreys - R. Cormack - J. Haldon (eds.), The Oxford Handbook of Byzantine Studies, Oxford 2008, pp. 827-914, where the period $300-650$ is referred to as late antique or early Byzantine according to the contributor's perspective.

41 Formally: R. Cantarella, Poeti bizantini. Volume primo: Testi. Volume secondo: Introduzione, traduzione e commento [Edizioni dell'Università Cattolica del Sacro Cuore. Serie «Corsi Universitari» 21-22], Milano 1948, vol. 2, pp. 2-3.

42 Informally: Young/Ayres/Louth (as above n. 23).

43 Formally: Krumbacher, GBL ${ }^{1}$ and GBL ${ }^{2}$ as forced by Iwan von Müller; A. Kambylis, Abriß der byzantinischen Literatur, in H.-G. Nesselrath (ed.), Einleitung in die griechische Philologie, Stuttgart - Leipzig 1997, pp. 316-342; Rosenqvist, Die byzantinische Literatur (as above n. 2), pp. 1-3.

44 Formally: Lauxtermann, Byzantine Poetry (as above n. 29); Kazhdan, History (as above n. 2). Informally: Krumbacher, GBL ${ }^{1}$ (as above n. 4); Howard Johnston (as above n. 36), pp. 1-15 from a historian's perspective. $\mathrm{AD} 700)$.

45 Stephenson (as above n. 29), p. xxiv (with no explanation for the choice of 
described as «innovative», sometimes times even as «original». ${ }^{46}$ Yet, when they are compared to each other in their relevant environment, they do not offer the image of a clear and conscious break; on the contrary, they present exactly the kind of overlap of non-synchronisms consisting of particular continuities and discontinuities.

However, towards the end of the reign of Diocletian (AD 284305) we find two authors who, in my opinion, meet the criteria for a structural break in literary production. These are L. Caecilius Firmianus Lactantius ( $†$ ca. 325/6) and Eusebios of Caesarea (†339). ${ }^{47}$ Both were faced with the same very serious crisis, that is, the «great»

46 See, indicatively, the respective remarks by Al. Cameron, Poetry and Literary Culture in Late Antiquity, in Swain/Edwards (as above n. 28), pp. 327-354 and Poets and Pagans in Byzantine Egypt, in R.S. Bagnall (ed.), Egypt in the Byzantine World, 300-700, Cambridge 2007, pp. 21-46; A. Kaldellis, Procopius of Caesarea: Tyranny, History, and Philosophy at the End of Antiquity, Philadelphia 2004, pp. 62-93; J. Elsner, The Rhetoric of Buildings in the «De Aedificiis» of Procopius, in L. James (ed.), Art and Text in Byzantine Culture, Cambridge 2007, pp. 33-57; G. Kelly, Ammianus Marcellinus: The Allusive Historian, Cambridge 2008; N. Hopkinson (ed.), Studies in the «Dionysiaca» of Nonnus [Cambridge Philological Society. Supplementary Volume 20], Cambridge 1994; D. Accorinti, Poésie et poétique dans l'ceuvre de Nonnos de Panopolis, in P. Odorico - P.A. Agapitos - M. Hinterberger (eds.), «Doux remède...»: Poésie et poétique à Byzance [Dossiers Byzantins 9], Paris 2009, pp. 67-98; A.M. Taragna, «Les apparances sont trompeuse»: Ruse, fiction et illusion chez George de Pisidie, in Odorico/Agapitos/ Hinterberger, pp. 121-140; J. Koder, Romanos: Die Hymnen [Bibliothek der Griechischen Literatur 62/64], Stuttgart 2005-2006 with substantial bibliography.

47 For the works of the two authors, the abbreviations and editions used in the present study see below the appendix on pp. 47-48. For all technical matters concerning the life and works of these two authors, I refer the reader to the following broader studies (in chronological order), though I do not necessarily agree with all of their proposals. On Lactantius: J. Fontaine - M. Perrin (eds.), Lactance et son temps: recherches actuelles (Actes du IVe Colloque d'Études bistoriques et patristiques. Chantilly, septembre 1976), Paris 1978; R.M. Ogilvie, The Library of Lactantius, Oxford 1978; E. Heck, MH @EOMAXEIN oder: Die Bestrafung des Gottesverächters. Untersuchungen zu Bekämpfung und Aneignung römischer religio bei Tertulian, Cyprian und Laktanz, Frankfurt a.M. 1987; A. Wlosok, L. Caecilius Firmianus Lactantius, in Herzog (as above n. 32), pp. 375-404; J. Bryce, The Library of Lactantius, New York 1990. On Eusebios: R.M. Grant, Eusebius as Church Historian, Oxford 1980; T.D. Barnes, Constantine and Eusebius, Cambridge, MA 1981; F. Winkelmann, Euseb von Kaisareia: Der Vater der

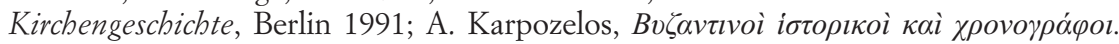

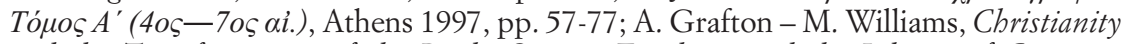
and the Transformation of the Book: Origen, Eusebius, and the Library of Caesarea, Cambridge, MA 2006; W.T. Treadgold, The Early Byzantine Historians, Basingstoke New York 2007, pp. 23-46. 
persecution of $303-313 .{ }^{48}$ Lactantius resigned from his post as teacher of rhetoric in Nicomedia (invited there by Diocletian), when he became an eyewitness to the beginning of the persecution in February 303, while, between 307 and 310, Eusebios was imprisoned and his teacher and protector Pamphilos executed.

Both authors entertained relations with Emperor Constantine. Lactantius had probably met him in Nicomedia before 306, while, later, on the emperor's invitation, he became teacher to his son Crispus in 315. It is to Constantine that Lactantius dedicated the second edition of his Divine Institutes in 325, that is, after Constantine's sole emperorship in 324. Eusebios met Constantine at the Council of Nicaea (summer of 325), while thereafter he had a «professional» exchange of letters with him. Eusebios declaimed a panegyrical oration in Jerusalem in September 335, and another one in Constantinople in July 336 during the celebration of the emperor's tricennalia.

Eusebios and Lactantius decided to dedicate their efforts to the systematic (historical and didactic) presentation of Christianity as (i) an autonomous religion distinct from «Hellenism» and «Judaism», ${ }^{49}$ (ii) an autonomous system of thought, and (iii) a historically realized decision of God concerning the path of humanity towards truth and salvation after death. The extended production of both authors includes apologetic, theological and historical works. However, these characterizations have to be placed in quotation marks since most of their works do not appear in a generic form instantly or even easily recognizable in relation to Ancient Greek, Latin, or earlier Christian literature. Both authors know to a certain extent the other «ecumenical» language, a knowledge that allows them to have some perspective of the other «ecumenical» literature as well.

The various works of the two authors present strong similarities; let me briefly mention the most obvious:

48 See A. Marcone, La politica religiosa: dall'ultima persecuzione alla toleranza, in Carandini/Cracco Ruggini/Giardina (as above n. 13), vol. 3.1, pp. 223-245; G. Clarke, Third-century Christianity, in A.K. Bowman - P. Garnsey - Av. Cameron (eds.), The Cambridge Ancient History. Second Edition. Volume XII: The Crisis of Empire, A.D. 193-337, Cambridge 2005, pp. 589-671, specifically pp. 647-665.

49 On this particular issue see the collection of papers in H.W. Attridge - G. Hatta (eds.), Eusebius, Christianity, and Judaism, Detroit 1992 and now A.P. Johnson, Ethnicity and Argument in Eusebius" «Praeparatio Evangelica», Oxford 2006. 
(i) The HE of Eusebios and the DMP of Lactantius, despite their historical subject, stand completely outside the framework of political historiography on the levels of content, structure and style..$^{50}$

(ii) Theological analysis and apologetic argumentation in their works tends rather to present the «proof» of the existence of Christianity and of Divine Providence for humanity, than actual theological thought. ${ }^{51}$ For example, the analysis in DI and PE/DE is conducted on the basis of a vast selection of passages from older -Greek, Latin, Jewish, Christian- texts, prose as well as poetry.

(iii) In all five of the above mentioned works (HE, DMP, DI, PE, DE) the two authors treat the selection of texts (for example, poetic passages or imperial documents) as an essential component of the truth -and, thus, of the validity- of their didactic discourse. ${ }^{52}$

(iv) Most of these works are dominated by a fluid form of composition that we could describe as a kind of «work-in-progress» with more

50 On the HE see E. Carotenuto, Tradizione e innovazione nella «Historia ecclesiastica» di Eusebio di Cesarea, Napoli 2001 and S. Morlet, L'introduction de l'Histoire écclesiastique d'Eusébe de Césarée (I, 2-4): étude génétique, littéraire et rhétorique, Revue des Études Augustiniennes 52 (2006) 57-95. On the DMP see A.S. Christensen, Lactantius the Historian: An Analysis of the «De mortibus persecutorum» [Opuscula Graecolatina 21], Copenhagen 1980; J.L. Creed, Lactantius: De Mortibus Persecutorum, Oxford 1984; B. Colot, Historiographie chrétienne et romanesque: Le «De mortibus persecutorum» de Lactance (250-325 ap. J.C.), Vigiliae Christianae 52 (2005) 135-151.

51 On Eusebios see M. Frede, Eusebius' Apologetic Writings, in M.J. Edwards - M.D. Goodman - S.R.F. Price (eds.), Apologetics in the Roman Empire: Pagans, Jews and Christians, Oxford 1999, pp. 223-250; M.J. Hollerich, Eusebius' of Caesarea «Commentary on Isaiah»: Christian Exegesis in the Age of Constantine, Oxford 1999. On Lactantius see M.J. Edwards, The Flowering of Latin Apologetic: Lactantius and Arnobius, in Edwards/Goodman/Price, pp. 197-221; E. Heck, «Defendere instituere»: Zum Selbstverständnis des Apologeten Lactanz, in A. Wlosok - F. Paschoud (eds.), L'apologétique chrétienne gréco-latine à l'époque prénicénienne [Entretiens sur l'Antiquité classique 51], Genève 2005, pp. 205-248.

52 On Eusebios see S. Morlet, Eusebius and the «testimonia»: Tradition and Originality, in A.-C. Jacobsen - J. Ulrich (eds.), Three Greek Apologists: Origen, Eusebius, and Athanasius [Early Christianity in the Context of Antiquity 3], Frankfurt a.M. 2007, pp. 93-157; A.P. Johnson, Eusebius" «Praeparatio Evangelica» as Literary Experiment, in S.F. Johnson (as above n. 37), pp. 67-89. On Lactantius see E. Heck, Lactanz und die Klassiker: Zu Theorie und Praxis der Verwendung beidnischer Literatur in christlicher Apologetik bei Lactanz, Philologus 132 (1988) 160-179 and the critical response by V. Buchheit, Cicero Inspiratus - Vergilius Propheta? Zur Wertung paganer Autoren bei Laktanz, Hermes 118 (1990) 357-372. 
than one «editions», while the texts often give the impression that they are entities composed out of distinct passages. ${ }^{53}$ Eusebios, in particular, presents writing as a process of transforming through narrative a group of selected passages into a $\sigma \omega \mu \alpha \dot{\tau} \iota \mathrm{v}$, a «book» (HE I 1.4):

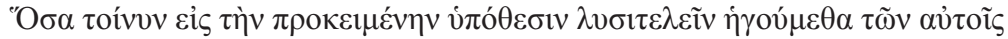

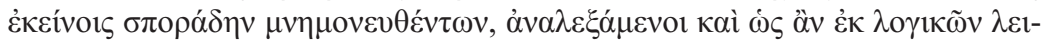

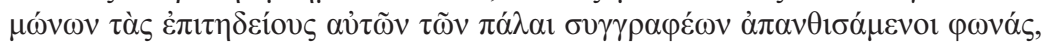

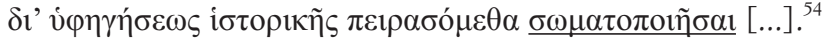

Thus from the scattered hints dropped by my predecessors I have picked out whatever seems relevant to the present subject, plucking like flowers in literary pastures the useful utterances of earlier writers to be formed through a historical account into a book (Williamson/Louth, p. 2 with modifications).

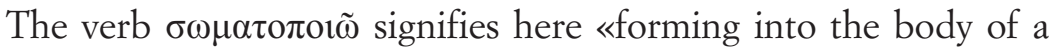
book», given that Eusebios in Book 4 of the De vita Constantini (a letter of Constantine quoted in Greek) uses the phrase $\sigma \omega \mu \alpha \dot{\tau} \tau 10 v \dot{\varepsilon} v$ $\delta i \varphi \theta \varepsilon \dot{\varepsilon} \rho \alpha \varsigma \zeta \dot{\varepsilon} \gamma \kappa \alpha \tau \alpha \sigma \kappa \varepsilon v ́ o 1 \zeta$ and refers to a parchment codex. ${ }^{55}$

53 See, indicatively, R.W. Burgess, The Dates and Editions of Eusebius' «Chronici canones» and «Historia ecclesiastica», The Journal of Theological Studies n.s. 48 (1997) 471-504; Av. Cameron - S.G. Hall, Eusebius: Life of Constantine. Introduction, Translation and Commentary, Oxford 1999, pp. 9-24; E. Heck, Die dualistischen Zusätze und die Kaiseranreden bei Lactanz, Heidelberg 1972; M. Perrin, Lactance: Épitomé des Institutions Divines [Sources Chrétiennes 335], Paris 1987, pp. 37-42; C. Ingremeau, Lactance: La colère de Dieu [Sources Chrétiennes 289], Paris 1982, pp. 41-44.

54 The words printed by me in italics are the technical terms Eusebios uses to describe the subject matter and narrative approach to his innovative work, in this case,

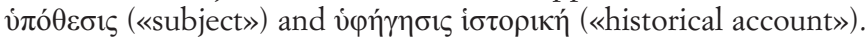

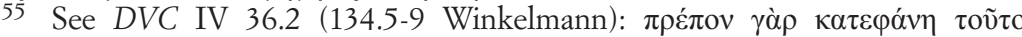

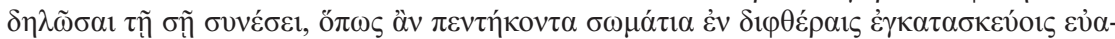

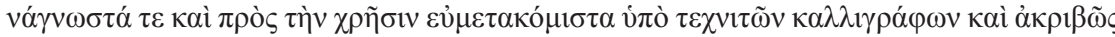

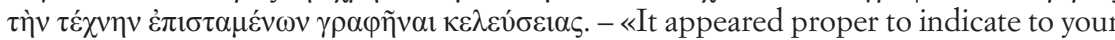
Intelligence that you should order fifty volumes with ornamental leather bindings, easily legible and convenient for portable use, to be copied by skilled calligraphists well trained in the art» (Cameron/Hall, p. 166). The rendering of the phrase $\sigma \omega \mu \alpha \dot{\tau} \tau 1 \alpha \dot{\varepsilon} v$

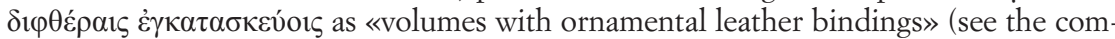
mentary in Cameron/Hall, p. 327), based on Barnes, Constantine and Eusebius (as above n. 47), pp. 118-119, goes back to C. Wendel, Der Bibel-Auftrag Kaiser Konstantins, Zentralblatt für Bibliothekwesen 56 (1939) 165-175. The latter's hypothesis 
(v) The wrath of God and the resulting punishment of Christianity's persecutors is explained historically and documented theologically in both authors: (a) Lactantius first writes the DMP (the collection of horrifying deaths of the persecutors in a direct line from Nero to Licinius) and, then, composes his treatise DID, wherein he developes and refines his theology of God's just anger, ${ }^{56}$ (b) Eusebios incorporates the deaths of the persecutors in the HE, putting a particular emphasis on Galerius and Maximinus, while he later transfers this passage from Book 8 of the HE to Book 1 of the DVC: $;^{57}$ (c) well beyond any older models, the death of the persecutor of Christians, as depicted by Lactantius and Eusebios, is elevated to one of the most powerful structural typoi for the representation of the death of evil characters in Christian historiography and hagiography. ${ }^{58}$

(vi) Both authors express a critical attitude towards their predecessors who supposedly treated similar topics:

(a) In the opening chapters of Book 5 of the Divine Institutes, Lactantius presents three older Latin apologetes of Christianity and their relevant works: Minucius Felix, Tertulian and Cyprian. ${ }^{59}$ He praises them individually for some of their

has been refuted by B. Atsalos, La terminologie du livre-manuscrit à l'époque byzantine. Premiére partie: Termes désignant le livre-manuscrit et l'écriture, Thessaloniki 1971 (reprinted ibidem 2001), pp. 115 n. 6, 118-119 and 147 (with the older bibliography). It is important to note that $\sigma \tilde{\omega} \mu \alpha$ translates the Latin term corpus for «volume» (see E.G. Turner, The Typology of the Early Codex, University of Pennsylvania Press 1977, pp. 83-84), and that in the fourth century the terms $\sigma \tilde{\omega} \mu \alpha$ and $\sigma \omega \mu \alpha \dot{\alpha} \tau 10 v$ are used for a parchment codex in contradistinction to the papyrus roll (see C.H. Roberts - T.C. Skeat, The Birth of the Codex, London 1983, p. 54 n. 1).

56 Ingremeau, La colère de Dieu (as above n. 53), pp. 45-56.

57 Cameron/Hall (as above n. 53), pp. 13-16.

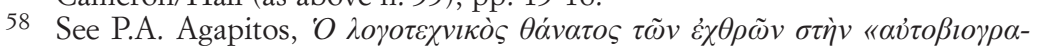

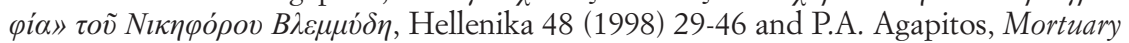
Typology in the Lives of Saints: Michael the Synkellos and Stephen the Younger, in P. Odorico - P.A. Agapitos (eds.), La vie des saints à Byzance: genre littéraire ou biographie historique? Actes du deuxiéme colloque international sur la littérature byzantine (Paris, juin 2002) [Dossiers Byzantins 4], Paris 2004, pp. 103-135.

59 For the three authors and their place in Latin apologetics see the broad treatment by M. Fiedrowicz, Apologie im Frühen Christentum: Die Kontroverse um den christlichen Wabrheitsanspruch in den ersten Jabrbunderten, Paderborn ${ }^{3} 2005$, pp. 6065, as well as the three papers by J.-C. Fredouille, L'apologétique chrétienne antique: 
efforts, but he mainly criticizes their partial or insufficient development of their topic. In the case of Cyprian and his Demetrianus he even criticizes the older author's style (DI V 4.7):

quod quia ille non fecit raptus eximia eruditione divinarum litterarum, ut his solis contentus esset quibus fides constat, accessi deo inspirante, ut ego facerem et simul ut viam ceteris ad imitandum pararem.

Cyprian failed to do this because he was swept away by his own remarkable knowledge of divine literature; indeed, he was content with only those things which are the substance of our faith. Hence my own approach to the task, under the inspiration of God, and my approach also to the preparation of a path for others to emulate (Bowen/Garnsey, p. 290 with modifications).

(b) Similarly, Eusebios in the general preface to the Ecclesiastical History criticizes «the authors of old» and «the authors of ecclesiastical affairs» as having written in an insufficient or partial manner. ${ }^{60}$ At a much later point and in a very different context (HE VI 13.4-8), ${ }^{61}$ he praises comprehensively only one work of an older author, namely, Clemens of Alexandria and his Stromateis, ${ }^{62}$ a work that could be viewed as the only recog-

naissance d'un genre littéraire, Revue des Études Augustiniennes 38 (1992) 219-234; L'apologétique chrétienne antique: métamorphoses d'un genre polymorphe, Revue des Études Augustiniennes 41 (1995) 201-216; L'apologétique latine pré-constantinienne (Tertullien, Minucius Felix, Cyprien): essai de typologie, in Wlosok/Paschoud (as above n. 51), pp. 39-67.

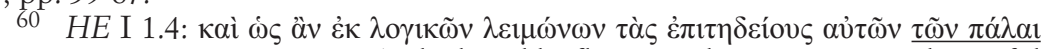

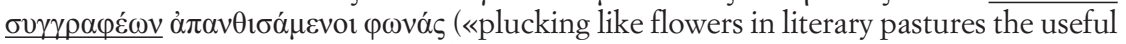

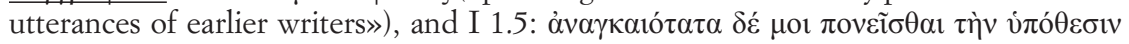

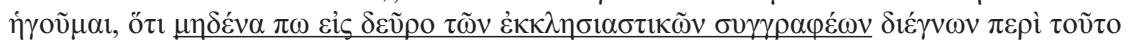

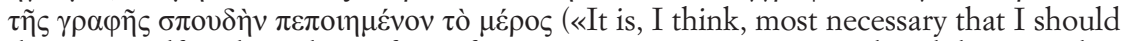
devote myself to this subject, for as far as I am aware no previous Church historian has been studiously interested in this kind of writing»); transl. in Williamson/Louth, p. 2 with modifications.

61 Schwartz, vol. 2, pp. 546.21-548.19; transl. in Williamson/Louth, pp. 190-191.

62 In particular, one should note Eusebios' emphasis on Clemens' following techniques: excerpting from various sources, historical-narrative exposition, providing the subject matter of his learned reading, mixture of Christian, Hebrew and Hellenic wisdom. On Clemens, his «programme» of the work and his methods in the Stromateis see the detailed analysis by A. Méhat, Étude sur les «Stromates» de Clément d'Alexandrie [Patristica Sorbonensia 7], Paris 1966, pp. 115-175. 
nizable conceptual model for his own «theological» works. ${ }^{63}$

(c) It is important to note that both authors present themselves as doing something «different» or «new»..$^{64}$ On the one hand, Lactantius, twenty lines before his criticism of Cyprian just quoted, writes in relation to Tertulian's Apologeticus (DI V 4.3):

aliud est accusantibus respondere, quod in defensione aut negatione sola positum est, aliud instituere, quod nos facimus, in quo necesse est doctrinae totius substantiam contineri.

there is a difference between merely responding to attacks, when defence and denial is the sole form, and setting up something new, which is what I am doing, when the full doctrinal content has to be in place (Bowen/Garnsey, p. 290).

Eusebios, on the other hand, makes two important statements concerning his pioneering and different «narrative discourse»

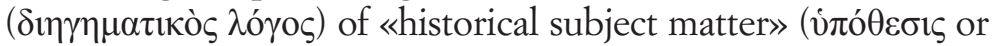
vं $\left.\eta^{\prime} \eta \sigma \mathrm{s}\right)$. The first statement appears in the preface to Book 1 of the Ecclesiastical History, the second governs the preface to the same work's Book 5 ( $H E$ I 1.3, and V pr.3-4 respectively):

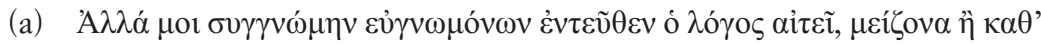

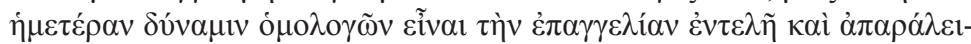

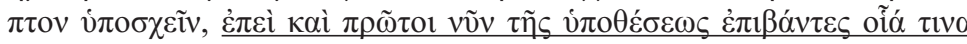

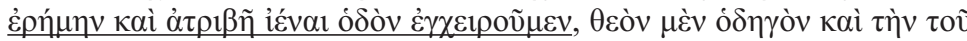

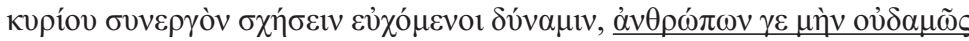

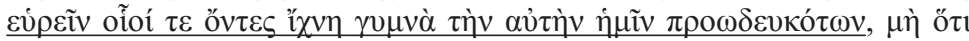

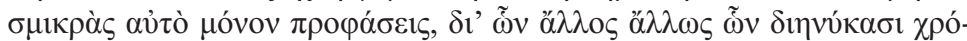

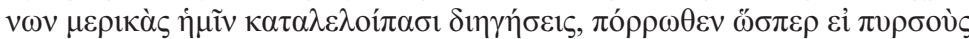

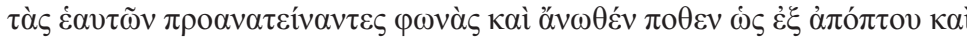

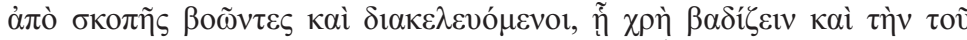

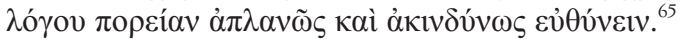

63 On Eusebios and Clemens in Book 6 of the HE see Johnson, Eusebius «Praeparatio Evangelica» (as above n. 52), pp. 75-83 (in relation to the device of excerpting).

64 P.G. van der Nat, Zu den Voraussetzungen der christlichen lateinischen Literatur: Die Zeugnisse von Minucius Felix und Laktanz, in Fuhrmann (as above n. 32), pp. 191-234 and the references in n. 51.

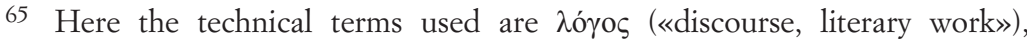


I trust that kindly disposed readers will pardon the deficiencies of my discourse, for I confess that my powers are inadequate to do full justice to so ambitious an undertaking. I am the first to venture on such a subject and to set out on what is indeed a lonely and untrodden path; but I pray that I may have God to guide me and the power of the Lord to assist me. As for men, I have failed to find any clear footprints of those who have gone this way before me; only minor remarks, by which in differing fashions they have left us partial narratives of their own lifetimes. Raising their voices like warning lights far ahead and calling out as from a distant watch-tower perched on some hill, they make clear to me by what path I must walk and guide the course of my work if I am to reach my goal in safety (Williamson/Louth, p. 2 with modifications).

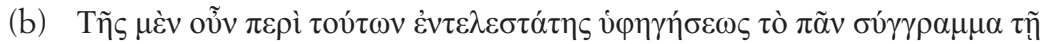

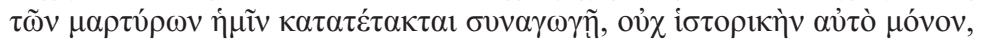

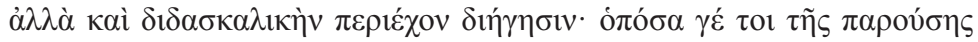

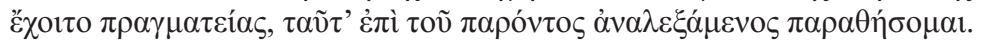

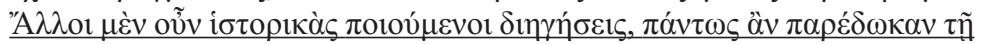

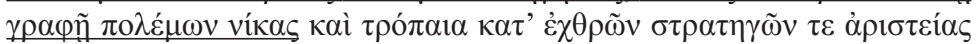

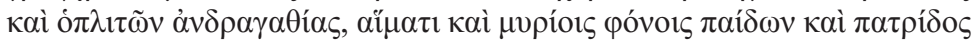

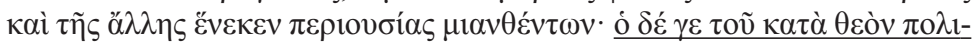

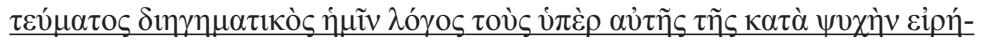

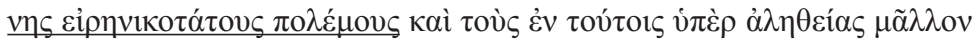

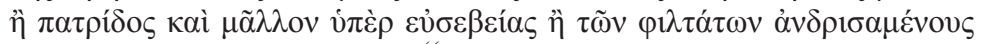

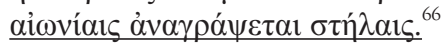

The entire work about the most complete account of these things has been inserted in my Collection of Martyrs, containing not only a historical but also a didactic narrative. For the moment I will content myself with quoting such passages as are relevant to the present treatise. Other authors, having produced historical narratives, transmitted in writing victories in war and triumphs over enemies, the exploits of the commanders and the heroism of their men, stained with the blood of the thousands they have slaughtered for the sake of children and country and possessions; it is peaceful wars, fought for the very peace of the soul, and men who in such wars have fought manfully for truth rather than for country, for true religion rather than for their dear ones, that my narrative

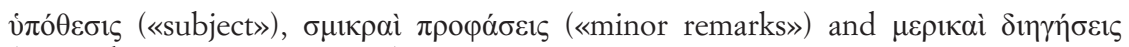
(«partial narratives/accounts»).

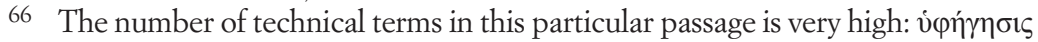

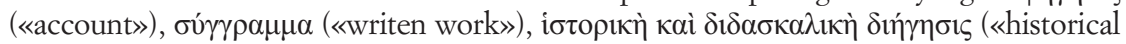

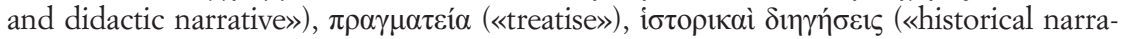

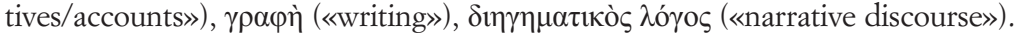


discourse of the polity according to God will inscribe on imperishable monuments (Williamson/Louth, p. 138 with substantial modifications).

(vii) Both authors strongly react to the same text. It is the $\Phi \iota \lambda \alpha \lambda \eta \dot{\eta} \theta \eta \varsigma$ («Lover of Truth»), a now lost polemical treatise against Christians by Sossianos Hierokles, commander of Bithynia when the persecution was formally announced. Sossianos undertook a comparison between Christ as represented in the Gospels and Apollonios of Tyana as represented in Philostratos' Life of Apollonios (ca. AD 220). On the one hand, Lactantius was present at a public reading of the work just before the beginning of the persecution; he criticizes the author in Book 5 of the Divine Institutes (V 2.12-3.24). On the other hand, Eusebios writes a brief essay against Sossianos and his inappropriate comparison between Christ and Apollonios as wonderworking men, though doubts have been expressed concerning the Eusebian paternity of the Contra Hieroclem. ${ }^{67}$

Beyond these actual similarities, there is another point that relates Lactantius to Eusebios. Both authors have been the subject of a debate concerning the literary genres to which their works belong, on the one hand, Lactantius' De ira dei and De mortibus persecutorum, on the other, Eusebios' Historia Ecclesiastica and De vita Constantini. The strongest disagreements concern the DMP and the DVC as «historiographical» works. ${ }^{68}$ In the case of the $D V C$ especially, the most complex hypotheses have been proposed about how the text was actually composed and to what genre it belongs. These hypotheses are based on the presupposition that some recognizable ancient generic model must lie behind the $D V C .^{69}$ In my opinion, this particular work cannot be reduced to any ancient model or combination of models, and this in

67 These doubts were eloquently proposed by T. Hägg, Hierocles the Lover of Truth and Eusebius the Sophist, in T. Hägg, Parthenope: Selected Studies in Ancient Greek Fiction, 1969-2004, Copenhagen 2004, pp. 405-416 (originally published in 1992); they have been countered by S. Borzi, Sull'autenticità del «Contra Hieroclem» di Eusebio di Cesarea, Augustinianum 43 (2003) 397-416 and C.P. Jones, Apollonius of Tyana in Late Antiquity, in Johnson, Greek Literature (as above n. 37), pp. 49-64, specifically pp. 49-52.

68 On the DMP see the references above in n. 50.

69 See, for example, the debate between Timothy Barnes and Averil Cameron, going back to suggestions made by Giorgio Pasquali more than hundred years ago: T.D. Barnes, Panegyric, History and Hagiography in Eusebius' "Life of Constantine», in R. 
contrast to the Life of Origenes in Book 6 of the HE. This vita is clearly modelled on a specific ancient biographical subgenre, namely, the pagan philosopher's life as «preface» to his works. ${ }^{70}$ Eusebios chose this model because it served a wholly different ideological, didactic and literary purpose within the $H E$, than the purpose the $D V C$ was to serve as an autonomous biographical text. ${ }^{71}$

Even this brief and necessarily generalizing comparison of Lactantius and Eusebios shows that we are faced here with two authors who reflect through their works a wholly new code of communication with their audience. «New» in this context does not signify originality on the level of individual textual characteristics, since some of the characteristics pointed out above can be found in Hellenistic and Roman literature..$^{72} \ll N$ New» here describes the overall effect of and the deeper attitude

Williams (ed.), The Making of Orthodoxy: Essays in Honour of Henry Chadwick, Cambridge 1989, pp. 94-123 and The Two Drafts of Eusebius's «Vita Constantini», in T.D. Barnes, From Eusebius to Augustine: Selected Papers 1982-1993, Aldershot 1994, no. XII; Av. Cameron, Eusebius" "Vita Constantini» and the Construction of Constantine, in M.J. Edwards - S.C.R. Swain (eds.), Portraits: Biographical Representation in the Greek and Latin Literature of the Roman Empire, Oxford 1997, pp. 145-174. For a summary of the debate see L. Franco, Eusebio di Cesarea: Vita di Constantino. Introduzione, traduzione e note, testo greco a fronte, Milano 2009, pp. 12-22.

70 See, indicatively, P. Cox, Biography in Late Antiquity: A Quest for the Holy Man [The Transformation of the Classical Heritage 5], Berkeley - Los Angeles 1983, pp.

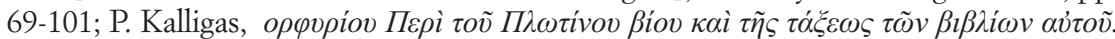

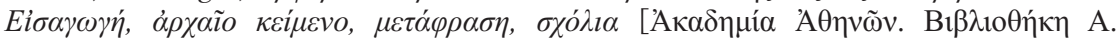
Mavov́on 1], Athens 1991, pp. 3-5; R. Goulet, Histoire et mystère: les vies de philosophes de l'antiquité tardive, in W.W. Ehlers (ed.), La biographie antique [Entretiens sur l'Antiquité Classique 44], Genève 1998, pp. 217-265; M.J. Edwards, Neoplatonic Saints: The Lives of Plotinus and Proclus by their Students. Translated with an Introduction [Translated Texts for Historians 35], Liverpool 2000, pp. xxxiv-xxxix; H.D. Saffrey - A.P. Segonds, Marinus: Proclus ou sur le bonheur, Paris 2002, pp. xli-lxix.

71 See now C. Markschies, Eusebius als Schriftsteller: Beobachtungen zum sechsten Buch der Kirchengeschichte, in A. Monaci Castagno (ed.), La biografia di Origene fra storia e agiografia. Atti del VI Convegno di Studi del Gruppo italiano di ricercha su Origene e la tradizione alessandrina (Torino 11-13 settembre 2002) [Biblioteca di Adamantius 1], Villa Verucchio 2004, pp. 35-50.

72 Callimachus with his Aetia, Apollonius of Rhodes with his Argonautica, Lucretius with his De rerum naturae and Ovid's Metamorphoses on the side of poetry (especially what concerns use of older material, scientific outlook, poetics, rivalry with predecessors); Cicero's and Seneca's philosophical essays (e.g. De natura deorum or De ira respectively), Plutarch's Moralia and Parallel Lives or Polybios' History on the side of prose (didactic-moral philosophy, narrative biography with a «point», didactic-moral historiography). 
to writing and its reception. Thus, the work of the two authors examined represents a structural break in the strongest terms. In my opinion, this break is not the coincidental result of overlapping asynchronisms, but a conscious attempt to introduce a specific and broadly valid ideological change. In the works of Lactantius and Eusebios we might recognize a series of seven «internal operative principles» that determine a new aesthetic framework for each individual text. ${ }^{73}$ These principles are:

(i) CENTRICITY: The text focuses on a marked structural or conceptual centre placed within a clearly hierarchical disposition. For example, Lactantius turns the death of Galerius into the narrative and moral focus point of $D M P,{ }^{74}$ while Eusebios does this with the great persecution in Book 8 of the $H E$, already emphasized in the hierarchical disposition of the immense opening sentence to the preface of Book $1 .^{75} \mathrm{~A}$ similar centre is the new and true place of Christianity as opposed to Hellenism and Judaism, assigned by Eusebios in the $P E$ and the $D E{ }^{76}$ Lactantius elevates Book 5 of the $D I$ on justice with its fifth address to Constantine and its second introduction to the work's historiographical centre, thus leading his readers to the theological culmination of Books 6 and $7 .^{77}$

(ii) COUNTERLINEARITY: We observe the cancellation of linear

73 For the following interpretative approach see R. Ingarden, Das literarische Kunstwerk, Tübingen ${ }^{4} 1972$, pp. 25-196 and H.-G. Gadamer, Wabrbeit und Methode: Grundzüge einer philosophischen Hermeneutik, Tübingen ${ }^{5} 1985$, pp. 107-174. For an application of this approach in my own scholarly work see P.A. Agapitos, «Quellenforschung» and/or Literary Criticism. Narrative Structures in Byzantine Historical Writings: A Comment, Symbolae Osloenses 73 (1998) 24-29 and 'H $\theta \dot{\delta} \sigma \eta \tau \tilde{\eta} \varsigma$

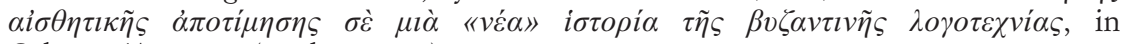
Odorico/Agapitos (as above n. 1), pp. 185-232.

74 See the statement in the preface about the deaths of the recent persecutors (DMP 1.7) and, then, the strong focusing on Galerius -the «second Maximian», as Lactantius calls him- at DMP $31 \mathrm{ff}$.

75 In the opening sentence (HE I 1.1-2) the catalogue of historical subjects to

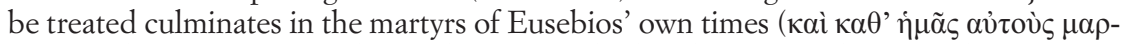
$\tau u ́ p ı$ ). The preface to Book 8 picks up exactly the phrasing of the general preface. In its first edition, the $H E$ ended with the full description of Galerius' disease, decree of tolerance, and death, including a comment on Galerius' major role in the great persecution (see the Appendix to HE VIII 17.11 on p. 796.1-9 Schwartz).

76 PE I 2 and DE I 1-2 (with direct references to the opening chapters of the PE).

77 DI V 1-4 (the chapters that include the positioning of the work in its «apologetic tradition»). 
structures (in other words, of structural bypotaxis) that would allow the multiple and in-depth connection of the text's recognizable parts. ${ }^{78}$ For example, the overall structure of the DID or of the $H E$ and the DVC is not organized along linear and hypotactical sequences of narrative or argumentative sections. ${ }^{79}$

(iii) PARATACTICALITY: Instead of bypotaxis, the structure of the text presents a paratactical organization of its smaller units, in other words, we find a clearly observable sequence of units all placed on the same narrative level. ${ }^{80}$

(iv) COMPARTMENTALIZATION: The smaller units are highlighted through some kind of strong marking as autonomous and often «water-tight» compartments. In this way, the impression is given that the removal or insertion of one or more compartments would not affect the text's macrostructure. One might look at works such as the DMP, the EDI, the $H E$ and the $D E .^{81}$

(v) NON-CLOSURE: The text does not seem to reach a recognizable

78 One might refer to Thucydides' Peloponnesian War as the most telling example of stylistic and structural bypotaxis in classical ancient Greek prose, a historian admired by some but not all ancient critics. On Thucydidean language and style see, indicatively, J.S. Rusten, Thucydides: The Peloponnesian War. Book II, Cambridge 1989, pp. 21-28 and E.J. Bakker, Contract and Design: Thucydides' Writing, in A. Rengakos A. Tsakmakis (eds.), Brill's Companion to Thucydides, Leiden 2006, pp. 109-129 with substantial bibliography.

79 On DID see the structural analysis by Ingremeau, La colère de Dieu (as above n. 53), pp. 37-41; on HE see Grant (as above n. 47), pp. 22-32 and Carotenuto (as above n. 50), pp. 16-24; on the DVC see the overall plan of the work as presented in Cameron/Hall (as above n. 53), pp. 24-27.

80 For Lactantius see, indicatively, DMP 3-6, the loose series of persecuting emperors (with the gap of approximately hundred-and-eighty years between Domitian and Decius); DID 3-6, where despite the syllogistic process of elimination of false hypotheses as to God's anger and goodness, the presentation of each hypothesis is paratactical. For Eusebios see, for example, HE III 5-24 (covering the time from Nero's death to the beginning of Trajan's reign), wherein we find a paratactical narrative interspersed with excerpts from authors such as Josephus or Clemens; DE III concerning the proofs of Christ's divine presence on earth, wherein a loose series of chapters presents a paratactical and associative structure, mixing excerpts ranging from the Prophets down to Philostratos' Life of Apollonios.

81 DMP 38-41, the sexual misdeeds of Maximinus Daia; EDI 1-12, presenting in dense syntactical and stylistic parataxis the main points of the original text (DI I 1.11); DE VIII, on the time of Christ's appearance among men; HE IV 21-30, a presentation of authors having written on the history of bishops, heresies and much more. 
closure, while in some cases it gives the impression of continuously awaiting further reworking. In other words, the notion of an authorially completed work is substantially weakened. One might compare the various levels of reworking in the $H E$, the two editions of the DI and its «reworking» as an epitome by the author himself. ${ }^{82}$

(vi) ABSORPTIVITY: The text visibly absorbs in different ways and for different purposes a multitude of various passages from older texts, for example, Eusebios' PE/DE and his partially lost General

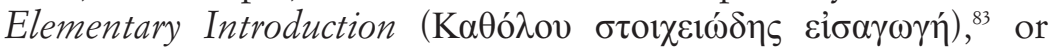
Lactantius' DI.

(vii) REVEALMENT: The text consciously reveals the mechanisms of its own structuring with continuous references to its structural parts and their «relation» to each other, for example, the DI, the $P E / D E$ and the $H E .^{84}$

Particularly important for the validity of the seven internal operative principles described and the new ideological and aesthetic code they represent is the fact that we find similar principles in the visual arts. One very promiment example is the Arch of Constantine in Rome. The arch was erected for the celebration of the emperor's decennalia and was dedicated in July 315; it is, thus, absolutely contemporary with Lactantius and Eusebios. ${ }^{85}$ The edifice consists of three distinct and dis-

82 For these three works see the references above n. 53.

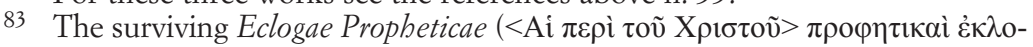
yoi) formed Books 6-9 of the General Elementary Introduction, as Eusebios himself remarks in the preface to Book 3 of the Eclogae Propheticae (Patrologia Graeca, vol. 22,

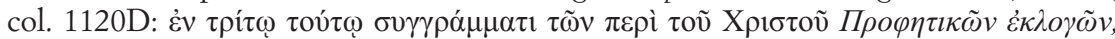

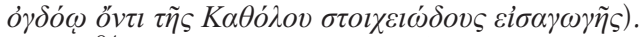

84 Lactantius' DI is an obvious case; one need only read the passage from one book to the next, for example, from Book 1 to 2, from Book 3 to 4, the opening of Book 5 with its second introduction to the whole work, the opening of Book 6 with its statement about the work's most important part, the end of Book 7 (and of the whole work). Similarly, Eusebius' DE reveals its structural system, moreover, it does so with systematic references to the relevant books of $P E$ (see in $D E$ the general preface, the preface to Book 2, the passage from Book 3 to 4, from Book 5 to 6, the preface to Book 9). Both these works have a strong didactic aim, and revealment could be perceived as inherent to this aim. But revealment is also found in the narrative works of the two authors. Thus, HE I 1.7-2.1 points to the narrative structure of the first books, but see also the preface to Book 2, the passage from Book 2 to 3, as well as the prefaces to Books 5 and 7 .

85 On the Arch of Constantine and the current archaeological findings see P. Pensabene - C. Panella (eds.), Arco di Constantino: Tra archeologia e archeometria [Studia Archaeologica 100], Roma 1999. 
tinguishable «elements»: (i) the original structural frame; (ii) large spolia of three different periods (Trajanic, Hadrianic, Aurelianic) from respective buildings of different types, visibly incorporated into the frame; it is now certain that these older Roman buildings were not demolished in 315 so as to spoliate the various reliefs used; ${ }^{86}$ (iii) Constantinian sculptures, for example, the rectangular reliefs above the smaller arches and under the Hadrianic roundels or the dedicatory inscription and the pair of grand roundels on the East and West sides.

We immediately recognize some of the principles governing the composition of the edifice: (a) centricity as reflected in the extreme prominence of the centre and its hierarchical disposition from the dedicatory inscription downwards; (b) counterlinearity as seen in the nonhypotactical disposition of the reliefs on the four walls of the arch, as well as within the Constantinian reliefs themselves; (c) paratacticality and compartmentalization displayed at a maximum degree, in contrast to similar older buildings, such as the arches of Titus (AD 82) or of Septimus Severus (AD 203), both in Rome; (d) absorptivity as witnessed in the incorporation of the older sculptural material. Furthermore, as with the debate concerning the genre and historical value of Lactantius' and Eusebios' «historiographical» works, a similar debate has been conducted about the aesthetic value of the Arch of Constantine and its place in the «declining» history of Roman architecture and sculpture. ${ }^{87}$ This debate has been almost exclusively conducted independently of the building's archaeological data. ${ }^{88}$

86 See D.E.E. Kleiner, Roman Sculpture, New Haven - London 1992, pp. 444455 and 484 (on the Arch of Constantine with full bibliography); P. Pensabene, Il reimpiego nell'età constantiniana a Roma, in G. Bonamente - F. Fusco (eds.), Costantino il Grande dall'antichità all'umanesimo: Colloquio sul Cristianesimo nel mondo antico, Macerata 18-20 dicembre 1990 [Università degli Studi di Macerata. Pubblicazioni della Facoltà di Lettere e Filosofia 67], Macerata 1992-1993, vol. 2, pp. 749-768; P. Pensabene, Progetto unitario e reimpiego nell'Arco di Costantino, in Pensabene/Panella, pp. 13-42.

87 See B. Berenson, The Arch of Constantine or the Decline of Form, London 1954 for the classic formulation of the decadence theory, and R. Bianchi Bandinelli, Rome: La fin de l'art antique, Paris 1970 (French translation of 1966 Italian original), pp. 70-85 on the Arch of Constantine and Constantinian sculpture with good b/w photographs of the Arch and its Constantinian freezes; this is the standard formulation of the «sympathetic» decadence theory.

88 For a critique of the debate and its ideology see J. Trilling, Late Antique and Sub-antique, or the «Decline of Form» Reconsidered, Dumbarton Oaks Papers 41 (1987) 469-476. For new proposals on the Arch and its place in late Roman (qua late antique) 


\section{PART III}

At this point, it will be necessary to draw some tentative conclusions. Faced with the unprecedented crisis of the great persecution, two important teachers and scholars decide -independantly the one of the other- to compose a series of works with the aim of proving the absolute truth and universal validity of a specific religious ideology. By criticizing most previous efforts in this direction, as well as rejecting in different ways other existing religious ideologies, Lactantius and Eusebios established through their substantial writings a new code of communication. This textual code, fully formulated by ca. 320, reflects a similar visual code expressed in the Constantinian arch of 315 . This synchronism indicates the existence of a strong ideological and aesthetic break in artistic production, but particularly so in literature. The break expressed through the works of Lactantius and Eusebios is indeed contemporary with Constantine but it is not intrinsically related to him as the «important» historical figure signalling the beginning of a new historical period in the conventional sense. In other words, it is not Constantine that is responsible for the break we detect in Lactantius and Eusebios; on the contrary, it is the two authors who are responsible for our image of Constantine and his place in the history of Christianity, an image which scholarship has been trying to revise over the past thirty years. ${ }^{89}$

art see B. Brenk, Spolia from Constantine to Charlemagne: Aesthetics versus Ideology, Dumbarton Oaks Papers 41 (1987) 103-109; P. Pierce, The Arch of Constantine: Propaganda and Ideology in Later Roman Art, Art History 12 (1989) 387-418; J. Elsner, From the Culture of Spolia to the Cult of Relics: The Arch of Constantine and the Genesis of Late Antique Forms, Papers of the British School at Rome 68 (2000) 149-184; E. Marlowe, Framing the Sun: The Arch of Constantine and the Roman Cityscape, Art Bulletin 88 (2006) 223-242. On the broader context of imperial monuments in this period see E. Mayer, Rom ist dort wo der Kaiser ist: Untersuchungen zu den Staatsdenkmälern des dezentralisierten Reiches von Diocletian bis zu Theodosius II. [Römisch-Germanisches Zentralmuseum, Forschungsinstitut für Vor- und Frühgeschichte. Mono-graphien 53], Mainz 2002.

89 See, indicatively, Bonamente/Fusco (as above n. 86); S.N.C. Lieu - D. Montserrat (eds.), Constantine: History, Historiography and Legend, London 1998; A. Marcone, Pagano e cristiano: Vita e mito di Constantino, Bari 2002; Bowman/Garnsey/ Cameron (as above n. 48), pp. 90-109; M. Amerise, Il battesimo di Constantino il Grande: Storia di una scomoda eredità, Stuttgart 2005; N. Lenski (ed.), The Cambridge Companion to the Age of Constantine, Cambridge 22012; R. van Dam, The Roman 
If we are to look for a historical figure to place next to the literary break, that figure would rather be Diocletian, his immense reform of the Roman empire and, most importantly, his decision to begin the persecution in February 303.90

A closer examination of Christian literary production until the beginning of the fifth century shows that later authors have been placed in an intertextually charged position, either by accepting or by competing with the «innovation» of Eusebios and Lactantius, for example, Hieronymus and Augustine as to Lactantius, ${ }^{91}$ Sokrates and Sozomenos the Church historians as to Eusebios. ${ }^{92}$

Moreover, after the deaths of the two authors, a gap of approximately twenty years can be detected in the writing of Christian texts because, if we are to judge by the surviving works, an openly classicizing Christian literary production begins to appear only after ca. 350360. In my opinion, there is no structural continuity between Graecoroman (qua «pagan») literature and Christian writing after Lactantius and Eusebios. The «classicism» of major Christian authors writing in Greek after ca. 355 (for example, Gregory of Nazianzus or Gregory of Nyssa) is a conscious literary stance of a «second-degree retrieval» in the formation of Christian discourse. ${ }^{93}$ It is not a contin-

Revolution of Constantine, Cambridge 2007; Demandt, Die Spätantike (as above n. 13), pp. 75-103; J. Bardill, Constantine, Divine Emperor of a Golden Christian Age, Cambridge 2012.

90 See the references above n. 48, as well as S. Corcoran, The Empire of the Tetrarchs: Imperial Pronouncements and Government AD 284-324, Oxford 1996 and A. Demandt - A. Goltz - H. Schlange-Schöningen (eds.), Diokletian und die Tetrarchie: Aspekte einer Zeitenwende [Millennium-Studien 1], Berlin - New York 2004.

91 Hieronymus devotes to him a brief biography in De viris illustribus (no. 80) and praises his Ciceronian eloquence (epist. 58, 10.2); Augustine acknowledges him as an important man in theological matters (DoctChrist. II 40.60-61). On these and other authors taking a position towards Lactantius see Wlosok, Lactantius (as above n. 48), 375-404 and A. Bowen - P. Garnsey (transl.), Lactantius: Divine Institutes [Translated Texts for Historians 40], Liverpool 2003, pp. 4-6.

92 Sokr. HistEccl. I 1.1-3 (1.4-14 Hansen) and Soz. HistEccl. I 1.12 (8.27-28 Bidez/Hansen).

93 For different interpretative approaches see Av. Cameron, Christianity and the Rhetoric of Empire: The Development of Christian Discourse [Sather Classical Lectures 55], Berkeley - Los Angeles 1991, pp. $15-46$ and 155-188, and P. Brown, Power and Persuasion in Late Antiquity: Towards a Christian Empire, Madison 1992, pp. 35-70 and 118-156. 
uation of the so-called second sophistic, ${ }^{94}$ nor is it a «third sophistic» as a newly coined term suggests. ${ }^{95}$

More importantly, the works of Lactantius and Eusebios fully reflect three overarching ideological concepts -intrinsically related to the seven internal operative principles proposed above- that three scholars have independently described for different phenomena between the sixth and the tenth century. These overarching concepts are:

(i) The «unitary thought», or la pensée unique as Polymnia Athanassiadi has called it; ${ }^{96}$ it is a demand towards a unitary and unified way of thinking about everything concerning the earthly and the heavenly kingdoms, in other words, religion, politics and social order. Athanassiadi saw its inception -and, thus, the rise of intolerance- in the middle of the third century in connection with the famous decree of Emperior Decius (AD 249) and placed its full development in the age of Justinian. ${ }^{97}$

(ii) The «collection culture», or la cultura della sylloge as Paolo Odorico called it, ${ }^{98}$ in contradistinction to the term and concept «encyclopedism» used by Paul Lemerle for the age of Constantine VII Porphygennetos in the tenth century. ${ }^{99}$ It is a way of organizing

94 See, indicatively, T. Hägg, Gregory of Nazianzus: A New Lease of Life for the

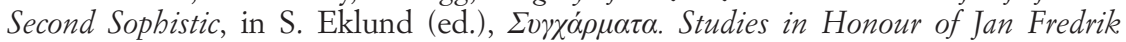
Kindstrand [Studia Graeca Upsaliensia 21], Uppsala 2006, pp. 113-127. For a critique of the whole concept see P. Brunt, The Bubble of the Second Sophistic, Bulletin of the Institute of Classical Studies 39 (1994) 25-52.

95 P.-L. Malosse - B. Schouler, Qu'est-ce que la Troisième Sophistique?, Lalies: Actes de Sessions de Linguistique et de Littérature 29 (2009) 161-224.

96 P. Athanassiadi, Vers la pensée unique: La montée de l'intolérance dans l'Antiquité tardive, Paris 2010, pp. 13-20.

97 Athanassiadi, Pensée unique, pp. 95-121; she sums up the process as «Justinien franchissait un Rubicon de la culture byzantine» (p. 116); similar thoughts, but presented from a positive perspective, had been expressed twenty years ago by Av. Cameron, Christianity and the Rhetoric of Empire (as above n. 97), pp. 189-221. M.T. Fögen, Die Enteignung der Wabrsager: Studien zum kaiserlichen Wissens-monopol in der Spätantike, Frankfurt a.M. 1993, had also reached similar conclusions by studying the laws concerning the regulation of divination and prochecy from the third to the early fifth century; see now C. Humphress, Orthodoxy and the Courts in Late Antiquity, Oxford 2007.

98 P. Odorico, La cultura della $\Sigma 0 \lambda \lambda o \gamma \eta$. 1) Il cosidetto enciclopedismo bizantino; 2) Le tavole del sapere di Giovanni Damasceno, Byzantinische Zeitschrift 83 (1990) 1-21.

99 Lemerle (as above n. 17), p. 266. The concept goes back to Krumbacher, $\mathrm{GBL}^{2}$, p. 258, but was actually coined as a term for Byzantium by A. Dain, L'encyclopédisme de Constantin Porphyrogénète, Lettres d'Humanité 12 (1953) 64-81; see Odorico, pp. 1-8. 
knowledge and thinking that brings together vast material in a supposedly «static» manner. ${ }^{100}$

(iii) The «cumulative aesthetic», as termed by Ja Elsner, for understanding the particularly three-dimentional and hierarchical organization of texts and buildings observable in the sixth century. ${ }^{101}$ Elsner based his analysis on a comparative examination of Prokopios' Buildings and Justinian's Hagia Sophia. ${ }^{102}$

The three concepts were proposed in order to explain the nature of developments that lead away from the world of Late Antiquity and towards Byzantine culture. ${ }^{103}$ However, all three concepts are fully present in the works of Lactantius and Eusebios: the unitary thought demands an ideological singularity and unity, as well as simultaneous inclusivity and exclusivity; the collection culture defines to a substantial

100 For the ancient traditions of excerpting texts and collecting passages see, indicatively, J. Mansfeld, Prolegomena: Questions to be Settled before the Study of an Author, or a Text [Philosophia Antiqua 61], Leiden 1994 and G.H. Snyder, Teachers and Texts in the Ancient World: Philosophers, Jews, and Christians, New York 2000.

101 J. Elsner, Late Antique Art: The Problem of the Concept and the Cumulative Aesthetic, in S. Swain - M. Edwards (eds.), Approaching Late Antiquity: The Transformation from Early to Late Empire, Oxford 2004, pp. 271-309.

$102 \mathrm{~J}$. Elsner, The Rhetoric of Buildings in the «De Aedificiis» of Procopius, in L. James (ed.), Art and Text in Byzantine Culture, Cambridge 2007, pp. 33-57. On the Mepi $\kappa \tau \imath \sigma \mu \alpha \dot{\tau} \omega v$ see the broad spectrum of papers in Ch. Roueché - J.-M. Carrié - N. Duval (eds.), Le «De aedificiis» de Procope (Actes du Colloque de Londres, 25-26 septembre 1998), Antiquite tardive 8 (2000) 7-180, especially pp. 9-79 on the history of the text, its nature and literary form, with contributions by B. Flusin, J. Howard-Johnston, D. Roques, Mary Whitby, Michael Whitby, R. Webb and E. Jeffreys.

103 Obviously, these developments had been studied before the formulation of the three concepts by Athanassiadi, Odorico and Elsner, though the description and analysis differs in various ways. In the case of religion and philosophy see $\mathrm{R}$. MacMullen, Christianizing the Roman Empire (A.D. 100-400), New Haven - London 1984; F.R. Trombley, Hellenic Religion and Christianization, c. 370-529 [Religions in the Graeco-Roman World 115.1-2], Leiden - New York 1993; P. Athanassiadi, La lutte pour l'orthodoxie dans le platonisme tardif: de Numénius à Damascius, Paris 2006; J.M. Schott, Christianity, Empire and the Making of Religion in Late Antiquity, Philadelphia 2008. In the case of education, scientific knowledge and literary culture see Av. Cameron, Education and Literary Culture, in Av. Cameron - P. Garnsey (eds.), The Cambridge Ancient History. Volume XIII: The Late Empire, A.D. 337-435, Cambridge 1998, pp. 665-707; H. Inglebert, Interpretatio christiana: les mutations des savoirs (cosmographie, géographie, ethnographie, histoire) dans l'Antiquité chrétienne (30-630 après J.-C.) [Collection des Études Augustiniennes. Série Antiquité 166], Paris 2001; in the case of art see Elsner, Art and the Roman Viewer (as above n. 32), pp. 159-245 (Part 2: The transformation of Roman art from Augustus to Justinian). 
extent the structure and content of the texts; the cumulative aesthetic supports the move towards overpowering hierarchical forms. Lactantius' Divine Institutes and Eusebios' Ecclesiastical History are the works that reflect to a maximum degree the seven internal operative principles and the three overarching ideological concepts described. Moreover, the DI and the $H E$ are also the two works with the broadest primary and secondary reception between the fourth and the tenth century.

All of the above makes obvious that in the works of Lactantius and Eusebios we are faced with a profound structural break in both Latin and Greek literature. The gradual literary developments in the West and the East after the middle of the fourth century also show that different Christian realizations of this break were taking place. We find a greater emphasis on poetry in the Latin speaking parts of the Mediterranean related, in my opinion, to the different type of patronage in the West, ${ }^{104}$ while a greater emphasis is placed on historiography and political writing in the Greek speaking parts due to different power structures and demands in the East. ${ }^{105}$

Thus, the structural break of 300 , as expressed by Lactantius and Eusebios, reflects a conscious departure from everything «antique» in structure, meaning and ideology. In this sense, the «end of antiquity» is clearly signalled in the work of these two outstanding Christian authors, despite the presence of Hellenic (qua pagan) literary production in the Greek language up to the early sixth century. ${ }^{106}$ In my opinion, Christian

104 See, for example, the greatly diverging evaluations of Greek and Latin poetry between the fourth and the sixth century proposed by Al. Cameron, Poetry and Literary Culture in Late Antiquity, in Swain/Edwards (as above n. 28), pp. 327-354 and M. Hose, Poesie aus der Schule: Überlegungen zur spätgriechischen Dichtung [Bayerische Akademie der Wissenschaften, Philosophisch-historische Klasse. Sitzungsberichte 2004.1], München 2004; personally, I find myself in agreement with Alan Cameron's mature synthesis.

105 See the negative evaluation by J.H.W.G. Liebeschuetz, The Decline and Fall of the Roman City, Oxford 2001, pp. 223-248 (The transformation of Greek literary culture under the influence of Christianity) and 318-341 (The transformation of literary culture in the West under the influence of Christianity); see the more positive evaluations by L. Pernot, La rhétorique de l'éloge dans le monde greco-romain [Collection des Études Augustiniennes. Série Antiquité 137-138], Paris 1993 and G. Marasco (ed.), Greek and Roman Historiography in Late Antiquity, Leiden 2003.

106 On this issues, with an emphasis on the developments in the West, see the detailled and highly critical reassessment by Al. Cameron, The Last Pagans of Rome, Oxford - New York 2011, pp. 33-92, 399-420 and 527-566. 
literature did not imitate Hellenic literature in some form of «natural symbiosis» but appropriated and absorbed it forcefully as society irrevocably moved towards the consolidation of a Christian -political, religious and social- view of the world. No comparable structural break appears in literary production until approximately 800, in the Greek East as well as in the Latin West. ${ }^{107}$ However, the structural break around 800 in Byzantium presupposes the break of 300 and its reception. ${ }^{108}$ Therefore, the break of 300 is for Byzantine literature a textually logical and ideologically significant beginning, while the break of 800 concerns an inner reorganization of Byzantine textual production along its various synchronisms and asynchronisms. Seen from this perspective, can it be a coincidence that around the year 800 the two parts of the world chronicle written by George Synkellos and Theophanes Confessor are divided exactly at the reign of Diocletian and his «great» persecution ${ }^{109}$

\section{ACKNOWLEDGEMENT}

The present paper is a revised version of a lecture given at the Universities of Milan and Oxford in November 2011; I am indebted to the critical comments of colleagues and graduate students in both audiences, in particular, Fabrizio Conca, Laura Franco, Mark Whittow and Marc Lauxtermann. I am further indepbted to Albrecht Berger, Averil Cameron, Diether Roderich Reinsch, Giuseppe Lozza and Ruth

107 See the essays by J.J. Contreni and W. Treadgold in W. Treadgold (ed.), Renaissances before the Renaissance: Cultural Revivals of Late Antiquity and the Middle Ages, Stanford 1984, pp. 59-74 (The Carolingian Renaissance) and 75-98 (The Macedonian Renaissance) respectively; see also J.J. Contreni, The Carolingian Renaissance: Education and Literary Culture, in R. McKitterick (ed.), The New Cambridge Medieval History. Volume II: c. 700 - c. 900, Cambridge 1995, pp. 709-757 (text) and 1013-1024 (bibliography).

108 See I. Ševčenko, The Search of the Past in Byzantium around the Year 800, Dumbarton Oaks Papers 46 (1992) 279-293.

109 For the view that both parts were, in fact, substantially written by George Synkellos see C. Mango - R. Scott, The Chronicle of Theophanes Confessor: Byzantine and Near Eastern History AD 284-813. Translated with Introduction and Commentary, Oxford 1997, pp. lii-lxiii. For a more cautious and balanced view, argueing for two

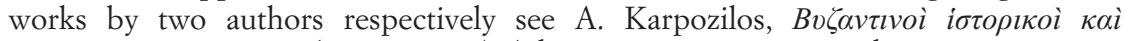

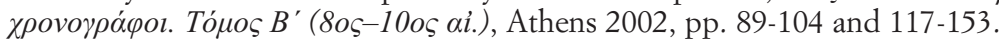


Macrides for providing me with various bibliographical items, and to Stavroula Cosntantinou and Martin Hinterberger for reading the final form of the paper. The text is based on sections from two different chapters of a study on the periodization of Byzantine literature, that I am currently preparing for publication. My thanks extend to the Research Committee of the University of Cyprus for covering my travel and research expenses with a generous grant.

\section{APPENDIX: THE WORKS OF EUSEBIOS AND LACTANTIUS}

I. Eusebios (surviving works in tentative chronological order)

Xpoviкò̀ кavóvєs - Chronicon (=Chron.), ca. 306/7, does not survive in Greek; the Latin version by Jerome edited by R. Helm, Die Griechische Christliche Schriftsteller: Eusebius Werke Bd. VII, Berlin ${ }^{3} 1984$; the Armenian version edited by J. Karst, Die Griechische Christliche Schriftsteller: Eusebius Werke Bd. V, Leipzig 1911.

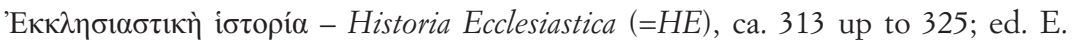
Schwartz -Th. Mommsen, Die Griechische Christliche Schriftsteller: Eusebius Werke Bd. II,1-3, Leipzig ${ }^{2}$ 1999; Engl. transl. by G.A. Williamson, Eusebius: The History of the Church from Christ to Constantine, revised and edited with a new introduction by A. Louth, London 1989.

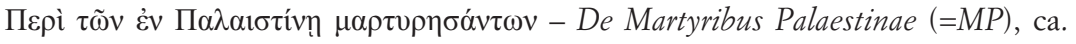
311; ed. E. Schwartz, Eusebius Werke Bd. II,2, pp. 907-950.

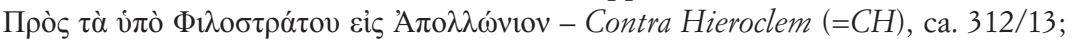
ed. and French transl. by M. Forrat - E. Des Places, Eusèbe de Césarée: Contre Hiéroclès [Sources Chrétiennes 333], Paris 1986; ed. and Engl. transl. by C.P. Jones, Philostratus: Apollonius of Tyana. Letters of Apollonius, Ancient Testimonia, Eusebius' Reply to Hierocles [The Loeb Classical Library 458], Cambridge, MA 2006, pp. 145-257.

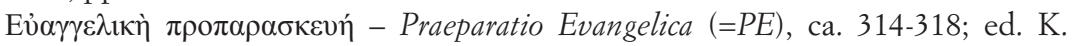
Mras, Die Griechische Christliche Schriftsteller: Eusebius Werke VIII,1-2, Berlin 1954-1956; ed. and French transl. by J. Sirinnelli - G. Schroeder - E. Des Places, Eusèbe de Césarée: La préparation évangélique [Sources Chrétiennes 206 (Bk. 1), 228 (Bks. 2-3), 262 (Bks. 4-5.17), 266 (Bks. 5.18-6), 215 (Bk. 7), 369 (Bks. 8-10), 292 (Bk. 11), 307 (Bks. 12-13), 338 (Bks. 14-15)], Paris 1974-1991.

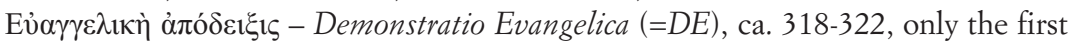
ten books out of twenty survive; ed. I.A. Heikel, Die Griechische Christliche Schriftsteller: Eusebius Werke VI, Leipzig 1913.

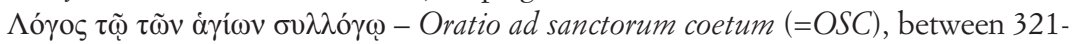
325, originally delivered by Constantine in Latin; ed. I.A. Heikel, Die Griechische Christliche Schriftsteller: Eusebius Werke I, Leipzig 1902, pp. 154-192; Engl. transl. by M.J. Edwards, Constantine and Christendom: The Oration to the Saints, the 
Greek and Latin Accounts of the Discovery of the Cross, the Edict of Constantine to Pope Silvester [Translated Texts for Historians 39], Liverpool 2003, pp. 1-62.

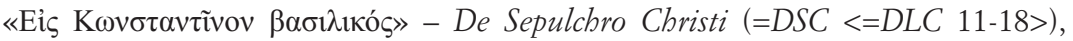
delivered on September 17, 335 in Jerusalem; ed. Heikel, Eusebius Werke I, pp. 223-259; Engl. transl. by H.A. Drake, In Praise of Constantine: A Historical Study and New Translation of Eusebius' Tricennial Orations [University of California Publications: Classical Studies 15], Berkeley - Los Angeles 1976, pp. 103-127.

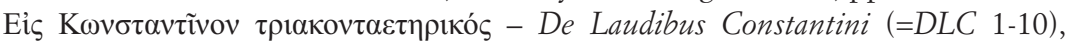
delivered on July 26, 336 in Constantinople; ed. Heikel, Eusebius Werke I, pp. 195223; Engl. transl. by Drake, In Praise of Constantine, pp. 83-102; French transl. by P. Maraval, Eusèbe de Césarée: La théologie politique de l'empire chrétien. Louanges de Constantin (Triantakontaétérikos). Introduction, traduction et notes, Paris 2001.

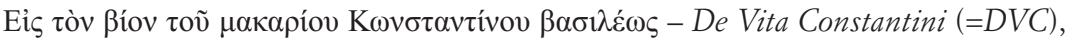
written between March 337 and May 339; ed. F. Winkelmann, Die Griechische Christliche Schriftsteller: Eusebius Werke I,1, Berlin ${ }^{2} 1991$; Engl. transl. by Av. Cameron - S.G. Hall, Eusebius: Life of Constantine. Introduction, Translation and Commentary, Oxford 1999; German transl. by H. Schneider, Eusebius von Caesarea: De Vita Constantini. Über das Leben Konstantins [Fontes Christiani 83], Turnhout 2007; Ital. transl. by L. Franco, Eusebio di Cesarea: Vita di Constantino. Introduzione, traduzione e note, testo greco a fronte, Milano 2009.

II. Lactantius (surviving works in tentative chronological order)

De Opificio Dei (=DOD), ca. 303/4; ed. and French transl. by M. Perrin, Lactance: L'ouvrage du Dieu créateur [Sources Chrétiennes 213-214], Paris 1974.

Divinae Institutiones (=DI), ca. 304-311; ed. by E. Heck - A. Wlosok, Bibliotheca Teubneriana, München - Leipzig - Berlin 2005-2009 (sofar 3 volumes, covering DI I-VI); ed. and French transl. by P. Monat - C. Ingremeau, Lactance: Institutions Divines [Sources Chrétiennes 326 (Bk. I), 337 (Bk. II), 377 (Bk. IV), 204-205 (Bk. V), 509 (Bk. VI)], Paris 1974-2007; Engl. transl. by A. Bowen - P. Garnsey, Lactantius: Divine Institutes [Translated Texts for Historians 40], Liverpool 2003. De Mortibus Persecutorum (=DMP), ca. 313-316; ed. and French transl. by J. Moreau, Lactance: De la mort des persécuteurs [Sources Chrétiennes 39.a-b], Paris 1954; ed. and Engl. transl. by J.L. Creed, Lactantius: De Mortibus Persecutorum, Oxford 1984.

De Ira Dei (=DID), between 316 and 325; ed. and French transl. by C. Ingremeau, Lactance: La colère de Dieu [Sources Chrétiennes 289], Paris 1982.

Epitome Divinarum Institutionum (=EDI), between 316 and 325; ed. by E. Heck A. Wlosok, Bibliotheca Teubneriana, Stuttgart - Leipzig 1994; ed. and French transl. by M. Perrin, Lactance: Épitomé des Institutions Divines [Sources Chrétiennes 335], Paris 1987. 